\title{
El conjunto religioso de Bāb Dukkāla: Levantamiento y análisis*
}

\section{The Religious Ensemble of Bāb Dukkāla: Survey and Analysis}

\author{
Iñigo Almela Legorburu \\ Escuela de Estudios Árabes, CSIC \\ http://orcid.org/0000-0002-9634-5374
}

En el presente trabajo se aborda el estudio de la mezquita de Bāb Dukkāla de Marrakech, una de las manifestaciones arquitectónicas que conoció esta ciudad bajo la dinastía saadí en el siglo XVI. Además de realizar un levantamiento preciso del edificio mediante fotogrametría, se documentan los anexos que la acompañan. Esta labor de documentación y análisis global nos ha permitido reconocer que se trata de un conjunto religioso planificado según un modelo bien integrado en su contexto urbano. Además de este aspecto, se analiza de forma general el espacio, la construcción y la ornamentación del conjunto, lo que nos permite caracterizar con mayor precisión la arquitectura realizada en este periodo histórico.

Palabras clave: Marrakech, saadí, mezquita, arquitectura religiosa.
The present research studies with depth the mosque of Bāb Dukkāla at Marrakech, an architectural masterpiece created under the Saadian dynasty during the sixteenth century. The main aim of this study is to complete an accurate survey, by photogrammetry process, of the main building, but also of the related and adjoining buildings. These documentation and global analysis allow us to recognize a clearly religious complex designed to be well integrated in its urban context. In addition, spatial, constructive and ornamental aspects of the complex are analyzed in order to understand the architecture developed during this historical period.

Key words: Marrakech, Saadian, mosque, religious architecture

* Este trabajo se ha desarrollado dentro del proyecto de investigación "Arquitectura saadí: la pervivencia de al-Andalus en el Magreb" (HAR2014-53006-P), bajo la dirección de Antonio Almagro Gorbea del grupo de investigación Laboratorio de Arqueología y Arquitectura de la Ciudad (código HUM-104 del Plan Andaluz de Investigación) de la Escuela de Estudios Árabes (CSIC).

Copyright: (C) 2017 CSIC. Este es un artículo de acceso abierto distribuido bajo los términos de la licencia de uso y distribución Creative Commons Attribution (CC-by) España 3.0. 


\section{Introducción}

La mezquita de Bāb Dukkāla y el complejo religioso del que forma parte, es un ejemplo importante de la actividad constructiva llevada a cabo por los sultanes saadíes en Marrakech. Junto a ella, en la capital del reino destacan otras fundaciones pías como el complejo de alMuwāssīn, la madraza Ibn Yūsuf, la rauda real junto a la mezquita de la Qașba y el complejo-zāwiya en torno al mausoleo de al-Ŷazūlī, entre otros edificios. El diseño de la mezquita, sus anexos y su relación con el espacio urbano debieron ser proyectados siguiendo unos patrones similares en los dos complejos religiosos saadíes, siendo el resultado de aplicar trazados tradicionales almohades y meriníes, así como innovaciones espaciales del momento. Los edificios no han llegado íntegros hasta nuestros días, mostrando las seculares transformaciones y avatares históricos; no obstante, esta situación es especialmente notable en el caso de Marrakech donde el perjuicio infligido al patrimonio arquitectónico debido a alteraciones de la medina se une a una serie de intervenciones restauradoras poco afortunadas. Esta destrucción material hace más necesario el presente estudio y la documentación exhaustiva de los edificios mediante planimetrías.

El procedimiento seguido en esta investigación, se basa en la práctica habitual empleada y desarrollada por los miembros del equipo del Laboratorio de Arqueología y Arquitectura de la Ciudad (LAAC) ${ }^{1}$. Una vez realizado el levantamiento del conjunto arquitectónico, y sobre la planimetría elaborada, es posible comenzar el análisis del edificio. Lamentablemente no se han podido aplicar técnicas de análisis estratigráfico y paramental, ya que las recientes intervenciones de restauración no permiten observar las fábricas ni diferenciar discontinuidades que sirvan para identificar fases constructivas o transformaciones. El análisis se aborda, por tanto: a nivel tipológico, utilitario, decorativo y constructivo, así como con un estudio comparativo con otros edificios semejantes (contemporáneos y anteriores).

\footnotetext{
${ }^{1}$ Almagro, Navarro y Orihuela, "Metodología en la conservación del patrimonio arquitectónico medieval", pp. 87-98; Almagro, "Análisis arqueológico del pabellón occidental del palacio al-Badī' de Marrakech"; Almagro, "El Salón Norte del Palacio al-Badī‘ de Marrakech: Estudio arqueológico e hipótesis sobre su forma original".
} 


\section{Historiografía}

La primera publicación relevante sobre este complejo data de 1954, en L'architecture Musulmane d'Occident de G. Marçais. En ella se le dedica un breve capítulo a la arquitectura saadí y alauí (Le Maroc sous les dynasties Chérifiennes), abordando el estudio global de sus diferentes expresiones arquitectónicas. Supone una aproximación conjunta de las dos mezquitas de Bāb Dukkāla y al-Muwāssīn, aportando la planta de las mismas y explicando con detalle algunos aspectos importantes de su trazado ${ }^{2}$.

En 1959, Deverdun, en su estudio sobre Marrakech, aborda las realizaciones de los sultanes saadíes a partir del trabajo de Marçais para comprender la evolución de la ciudad. Dentro del capítulo dedicado al renacimiento de la ciudad bajo el gobierno de Ahmad al-Manșūr aporta una cronología respecto a la mezquita de Bāb Dukkāla, reconociendo la autoridad que promueve el proyecto, e identifica la existencia de un gran conjunto religioso que guardaba similitud con el de al-Muwāssīn. Por su parte, Barrucand en 1985 en su obra Urbanisme princier en Islam, trató de manera superficial la ciudad de Marrakech, resumiendo las grandes intervenciones urbanas y arquitectónicas emprendidas por los sultanes saadíes ${ }^{3}$, si bien ya destaca el papel que las mezquitas y los complejos religiosos jugaron en el programa arquitectónico emprendido por el poder político.

Posteriormente Raji Elillah realizó una monografía en la que abordó de manera global toda la actividad constructiva llevada a cabo por los sultanes saadíes en Marrakech e incluyó una recopilación de planimetrías procedentes de la Inspection Regionale des Monuments Historiques de Marrakech y de los archivos de la Dirección de Patrimonio ${ }^{4}$.

\footnotetext{
${ }^{2}$ Marçais, L'architecture musulmane d'occident, pp. 385-386. Anteriormente H. Basset y H. Terrasse dentro de su trabajo sobre santuarios y fortalezas almohades (1932), recogieron algunos ejemplos posteriores en los que reconocían la continuación de los modelos tradicionales almohades. Entre ellos se encuentra la mezquita aljama de al-Muwāssīn y las intervenciones de Muley 'Abd Allāh en la mezquita almohade de la qașba. A partir de estos dos casos, en especial el primero, se identificaron los principales rasgos espaciales y decorativos, así como repararon en algunas particularidades propias de este periodo.

${ }^{3}$ Barrucand, Urbanisme princier en Islam: Meknès et les villes royales islamiques post-médiévales, pp. 111-122.

${ }^{4}$ Y. Raji Elillah, La Ville de Marrakech sous les Sa'adiens (16-17ème siècles): L'activité architecturale et le développement urbain, tesis doctoral inédita dirigida por $\mathrm{M}$. Barrucand y presentada en la Universidad de Paris-Sorbonne en 1996.
} 
Todo este material nos permite observar el estado de los edificios en diferentes fechas $y$, por tanto, datar relativamente las transformaciones acaecidas en las últimas restauraciones. En el último siglo las fachadas de la mezquita han sufrido modificaciones y la madraza ha sido parcialmente eliminada, en favor del acondicionamiento de las calles circundantes. La relevancia de este trabajo para el presente estudio es fundamental, ya que se documenta la mezquita y algunos de los anexos. Sin embargo, no existe una planimetría de conjunto que llegue a representar el complejo religioso. Se trata de planos parciales de cada edificio, y en muchos casos no corresponden con la realidad.

En 2001, Quentin Wilbaux se basa en el material de Raji Elillah para reconstruir la formación de la medina de Marrakech desde sus orígenes, en el siglo XI, hasta la época del protectorado, en el siglo XX. Aunque no entra en profundidad en el estudio de las construcciones, reconoce de nuevo la importancia que tienen los grandes complejos religiosos del periodo saadí y su impacto en la medina, así como en la formación y desarrollo de los barrios ${ }^{5}$. Por su parte, Rasha Alí ha estudiado exhaustivamente la ornamentación epigráfica monumental de la arquitectura saadí 6 .

Las fuentes árabes son bastante escuetas en cuanto a la información de la mezquita de Bāb Dukkāla y sus anexos, pero contamos con menciones en la Nuzhat al-ḥādī del historiador del siglo XVII al-Ifrānī y el texto de donaciones adjuntado por Aḥmad Ibn al-Qāộ̄, secretario y gerente bajo el gobierno de al-Manșūr, en su obra al-Muntaqà. Ambos hablan de la mezquita y de las fundaciones piadosas que constituyó la madre del sultán en beneficio de esa mezquita, aunque se contradicen entre sí con respecto a la fecha de construcción, como veremos más adelante.

\section{Datación y contexto histórico}

Las fuentes escritas pueden resultar confusas y contradictorias en cuanto a su datación, no obstante, la mayor parte de ellas atribuyen esta construcción y sus diversas dotaciones a la madre del sultán Aḥmad

\footnotetext{
${ }^{5}$ Wilbaux, La médina de Marrakech: formation des espaces urbains d'une ancienne capitale du Maroc, pp. 260-263.

${ }^{6} \mathrm{Ali}$, L'Épigraphie monumentale sa dienne au Maroc. 
al-Manșūr (1578-1603), conocida como Mas'ūda bt. Abū al-'Abbās Aḥmad b. 'Abd Allāh al-Wazkītī al-Warzazātī, mecenas de diferentes construcciones $^{7}$ y 1591/1000, fue enterrada en las tumbas saadíes ${ }^{8}$. Parece que buscó durante el reinado de su hijo favorecer las comunicaciones, y para ello invirtió en la reparación de rutas, edificación de alojamientos para caravanas y numerosos puentes como el del río Issil frente a la puerta de Bāb Dabbāg en Marrakech'.

Marçais y Deverdun la dataron de 1557-58 (periodo dentro del gobierno de 'Abd Allāh al-Gālib), siguiendo ambos la fecha aportada por al-Ifrānī:

"Y su madre (de Aḥmad al-Manșūr) al-ḥurra Mas'ūda hija del espléndido šayj Abū al-'Abbās Aḥmad b. 'Abd Allāh al-Wazkīî̀ al-Warzazātī era una benefactora deseosa de la construcción de monumentos (mafājir) y la acción del bien. Dijo en al-Muntaqà ${ }^{10}$ que ella construyó la mezquita del barrio de Bāb Dukkāla (masŷid al-ŷami ' bi-hawmat bāb dukkāla) dentro de la medina de Marrakech y le donó grandes fundaciones piadosas (awqāf). Era aquello en el año 965(1557-1558)."

Tal y como se menciona en el texto, Ibn al-Qāḍī en su obra al-Muntaqà al-maqșūr, nos indica que la construcción y sus anexos se vinculan a la madre de al-Manșūr: "Entre lo que ordenó edificar está la mezquita (al-masŷid) que construyó en Bāb Dukkāla en Marrakech. Una gran mezquita (masŷid 'ażim) en la que se realiza la congregación (alŷmu 'a). La dotó (habasat) de grandes rentas a través de fundaciones piadosas (waqf $f^{a n}$ 'azīm ${ }^{a n}$ )". A continuación, adjunta un texto de la fundación del habiz (taḥbīs) que data del mes de muharram de 995/1585 ${ }^{12}$. En él, se detallan las diversas donaciones (awqāf) entre las que constan tiendas junto a la alcaicería, casas, tomas de agua y terrenos de cultivo. A continuación, detalla que los derechos y beneficios perpetuos sobre las mismas se destinan para el mantenimiento de la mezquita y los salarios de imanes, alfaquíes, muecines y otros empleados, así como la

${ }^{7}$ Ibn al-Qāḍ̄i, Al-muntaqà al-maqșūr 'alà ma'ātīr al-jalīfa al-Manșūr, pp. 405-6, n. 1141; al-Nāșirī, Kitāa al-Istiqșā li-ajbār al-Magrib al-Aqsà, p. 126.

${ }^{8}$ Deverdun, Inscriptions arabes de Marrakech, inscr. n. 147.

${ }^{9}$ Según Deverdun los cinco puentes que sobrepasan el río Issil se pueden adscribir al periodo saadí.

${ }^{10}$ Ibn al-Qāḍī, Al-muntaqà al-maqșūr, p. 257.

${ }^{11}$ al-Ifrānī, Nozhet-Elhâdi, histoire de la dynastie saadienne au Maroc (1511-1670), p. 79 (trad. p. 140).

${ }_{12}$ Ibn al-Qāḍī, Al-muntaqà al-maqșūr, pp. 257-267. Esta fecha se mantiene en la versión que al-Nāṣirī relata en el siglo XIX, al-Nāṣirī, Kitāb al-Istiqșāa, pp. 117-118. 
finalización de la construcción. A partir de esta acta de fundación de bienes habices $(t a h b i \bar{s})$ señalada por E. Lévi-Provençal ${ }^{13}$, Deverdun supuso que constituía la referencia cronológica más importante, y nos informa así de la fecha de finalización de la mezquita en $1586^{14}$. La construcción de la mezquita, o más precisamente del oratorio y su biblioteca, habrían necesitado treinta años de trabajo, desde 1557-58 hasta 1585. Este largo periodo, que resulta excesivo, fue puesto en duda por Raji Elillah ${ }^{15}$, ya que dicho taḥbiss no fue el primer texto de donación atribuido a la mezquita. En una búsqueda archivística en los fondos de la antigua biblioteca de Ibn Yūsuf, este investigador localizó cierto número de manuscritos archivados como bienes de la mezquita. Entre ellos se encontraba una obra de jurisprudencia ( $f i q h)$ titulada Tahdīib al-mudawwana cuyo taḥbìs indica que la obra fue donada a la mezquita de al-Hurra por el anterior soberano saadí 'Abd Allāh al-Gālib en $1570-71 / 978^{16}$.

La muerte de Muley 'Abd Allāh puso fin a un sólido y continuo gobierno que fue sucedido por su hijo Muhammad al-Mutawakkil. Éste habría gobernado de manera tranquila de no haber sido por el apoyo que sus tíos 'Abd al-Malik y Ahmad recibieron del Imperio Otomano, bajo el que se refugiaron ante la amenaza de su hermano. Cuando se presentaron en Fez con un contingente turco-argelino, Muhammad abandonó la ciudad sin combate y se refugió en Marrakech. 'Abd alMalik no tardó en presentarse en la capital y la ocupó en 1576 sin que Muhammad mostrase capacidad de defensa y terminara huyendo ${ }^{17}$. Un último intento fallido de Muhammad para entrar en Marrakech en 1577 dio paso a su exilio en Portugal, donde al amparo del rey don Sebastián pudo organizar una fuerte expedición portuguesa que desembarcó en Arzila en julio de $1578^{18}$. Días después, la operación militar fue aplas-

${ }^{13}$ Lévi-Provençal, Les historiens des Chorfa, p. 108.

${ }^{14}$ Deverdun, Marrakech des origines à 1912, p. 413.

${ }^{15}$ Raji Elillah, La Ville de Marrakech, pp. 107-109.

${ }^{16}$ El autor de esta obra es Ḥalaf b. Abī al-Qāsim Abū Sa ‘̄id al-Azdī al-Barādi'ī. Esta actualmente en la biblioteca de İbn Yūsuf bajo la signatura 35/5. Entre las obras atribuidas a los bienes de la mezquita se encuentran tres tomos de un Corán asignado por lālla Mas'ūda en Ramadán 995/1585 (signatura 802) y un Corán comisionado por Muley Zaydān al-'Alawī.

${ }^{17}$ al-Nāṣirī, Kitāb al-Istiqșā, p. 64-66.

${ }^{18}$ Vajda, "Un recueil de textes historiques judéo-marocains", pp. 15-16; Ibn al-“Askar, Dawhat al-nāṣir li-maḥāsin man kāna bi-l-Magrib min mašāyj al-qarn al-'āsir, pp. 99. 
tada cerca de Alcazarquivir por las tropas de 'Abd al-Malik. La victoria, el 4 de agosto de 1578, tuvo consecuencias internacionales y consiguió para los jerifes una gloria y un fervor renovado. Conocida como la batalla de los Tres Reyes, durante su desenlace perecieron Don Sebastián rey de Portugal y Muley Muhammad en Wādī al-Majāzin y 'Abd alMalik falleció unos días después. El gran triunfador del evento y el que puso fin a los cuatro años de crisis, fue Ahmad, hermano de 'Abd alMalik. Éste fue proclamado en el campo de batalla con el sobrenombre de al-Manșūr.

Ambos documentos de donación denominan a la mezquita como al-Hurra, atestiguando que la construcción fue promovida por una integrante femenina de la familia del sultán ${ }^{19}$. Sin embargo, el espacio de tiempo comprendido entre ellos (15 años) vio diversos cambios políticos y hace que cada uno corresponda a un gobierno diferente ${ }^{20}$. Esto permite aceptar el largo proceso de culminación del complejo religioso; pudiendo la mezquita y su biblioteca, existir ya en el momento de la primera donación de libros del sultán 'Abd Allāh (1570). De esta manera, tomaría veracidad la fecha aportada por al-Ifrānī (965/1557-58), y la mezquita correspondería probablemente al gobierno de Muley 'Abd Allāh (1557-1574), en el que la ciudad conoció una gran cantidad de reformas urbanas, así como construcciones religiosas y públicas ${ }^{21}$. Por otro lado, algunos de los anexos y posibles reformas en la mezquita pudieron prolongarse hasta más allá de la segunda acta de donación (1585), puesto que en ella se hace alusión al destino de parte de los habices para sufragar la consumación de los trabajos de construcción. Esta intervención vendría a ser sin lugar a dudas la desempeñada por la madre de Aḥmad al-Manșūr.

${ }^{19}$ El título al-hurra es aplicado a distintas mujeres, tanto las nacidas en el seno de la dinastía, como esposas legítimas, así como concubinas desposadas, y hace referencia a la condición de libertad que disfrutaban, Boloix, Las sultanas de la Alhambra: las grandes desconocidas del reino nazari de Granada (siglos XIII-XV), p. 328.

${ }^{20}$ Como ya se ha dicho anteriormente la madre de Aḥmad al-Manșūr es citada en diversas obras como promotora sin hacerse alusión a ninguna otra mujer. Si no contemplamos la posibilidad de que la construcción fuese emprendida por una mujer anterior (quizás la madre de 'Abd Allāh), lālla Mas 'ūda tendría que haber disfrutado de una inmunidad considerable y de condiciones económicas muy favorables tras quedarse viuda de Muhammad al-Šayj, para poder sobrevivir y emprender tal proyecto durante el gobierno de su hijastro 'Abd Allāh enemistado por la sucesión con su hijo Aḥmad al-Manșūr. 


\section{El barrio de Bāb Dukkāla}

La naturaleza de los proyectos arquitectónicos religiosos saadíes, tiene un impacto considerable en la ciudad. En realidad, se trata de complejos arquitectónicos que giran en torno a las mezquitas mediante la construcción de diversos edificios complementarios a la práctica religiosa, como son los pabellones de abluciones, baños, fuentes, madrazas, escuelas coránicas, bibliotecas, etc. La implantación de la mezquita y sus anexos en el entramado de la ciudad jugó un papel importante en la formación, ampliación y restructuración de los barrios, así como en la estimulación de la vida urbana ${ }^{22}$. Independientemente de la cronología de los proyectos de al-Muwāssīn y Bāb Dukkāla, el modelo funcionó con éxito y fue empleado en ambas ocasiones. Así, la misma idea está presente en otros conjuntos contemporáneos como el que hay en torno a la zâwiya de al-Ŷazūlī o el nunca concluido de Jemaa el-Fna (Ŷ̄ami ‘al-fanā').

Por consiguiente, antes de abordar el análisis de las construcciones, es preciso atender a las características y morfología del contexto urbano en el que se insertan (fig. 1). Para ello se ha elaborado una planimetría del entorno del conjunto religioso en la que se han intentado identificar los diferentes usos (religioso, comercial y residencial), distinguir la jerarquía viaria y analizar las anomalías que atestigüen posibles transformaciones ${ }^{23}$.

Es complicado trazar un plano que represente el estado de la ciudad de Marrakech en época saadí, así como delimitar en él los barrios y diferentes espacios con los que contaba en el siglo XVI. Las fuentes no facilitan datos precisos ni concretos, y hasta el siglo XIX no contamos

${ }^{21}$ Este sultán emprendió la construcción de la mezquita de al-Muwāssīn edificada entre 1562 y 1571, de la mezquita de al-Qușūr en 1571, el maristán, el nuevo barrio judío de la Mellah y la zāwiya de sīdī Yūsuf b. 'Alī.

${ }^{22}$ Las mezquitas contribuyen en gran medida en la organización y estructuración de los barrios, aspecto que deriva del importante papel social y político que desempeñan en las ciudades y asentamientos, Trillo San José, "Mezquitas en al-Andalus: un espacio entre las comunidades y el poder", pp. 73-98.

${ }^{23}$ Para ello hemos usado de base el plano fotogramétrico elaborado por la S.N.P.T. por la cuenta del Ministerio de Interior, Dirección y Urbanismo, de Ordenación del Territorio y Medio Ambiente a partir de vistas aéreas efectuadas en 1987. Para retrotraernos a un estado más antiguo se ha usado la fotografía aérea de 1917 realizada por el ejército francés de ocupación actualmente conservada en la Inspection des Monuments de Marrakech. 


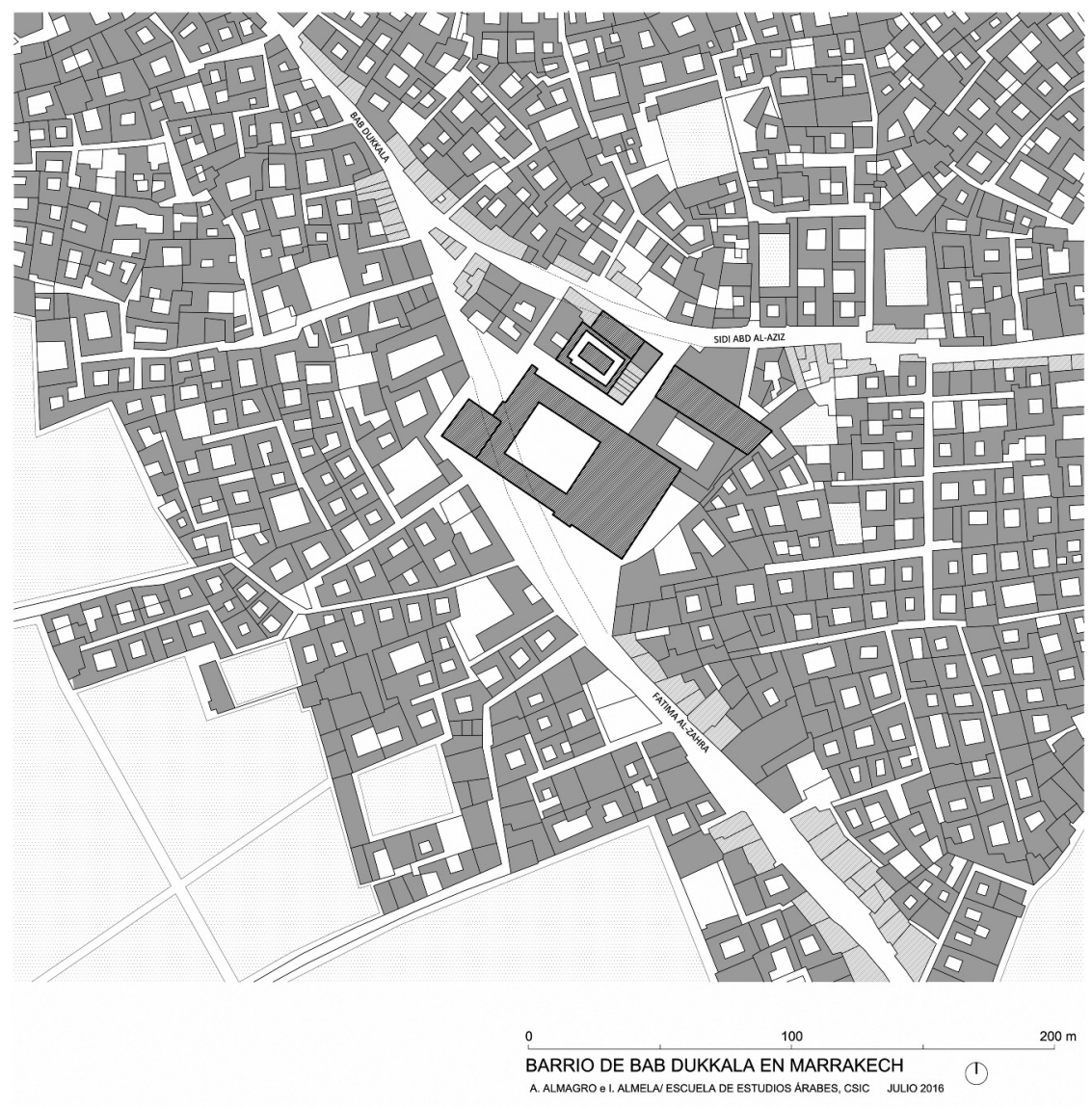

Figura 1. Plano del barrio de Bāb Dukkāla basado en la fotografía aérea de 1917.

con planos útiles ${ }^{24}$. Aunque están representados de manera ambigua, estos primeros planos nos permiten aproximarnos al paisaje urbano del momento, por supuesto, con la precaución de considerar el salto temporal y la evolución de la ciudad entre los siglos XVI y XIX. De acuerdo con la imagen aérea de 1917, en ese momento la medina no

${ }^{24}$ Se trata principalmente del plano de Washington de 1830, el plano de Lambert de 1867 y el plano de Larras de 1899. A esta dificultad, se suma la falta de una reglamentación que obligue a documentar los registros arqueológicos que subyacen en la medina cada vez que se hace una nueva remoción de tierras en los solares. 
estaba saturada y contaba con una gran superficie de solares cultivados o deshabitados. Los barrios se extendían dentro de las murallas como islas en torno a las arterias principales, concentrándose especialmente en el centro de la medina. Partiendo del proceso de densificación que experimentan las ciudades islámicas ${ }^{25} \mathrm{y}$ teniendo en cuenta los bruscos cambios demográficos que tuvo que sufrir la ciudad debido a los fenómenos políticos y a los ciclos de capitalidad y abandono, podemos advertir que en época saadí la ciudad tuvo que sentir el crecimiento de los barrios interiores, gracias a la estabilidad política y a las condiciones económicas. El crecimiento económico y demográfico del que disfrutó la ciudad durante los gobiernos estables de 'Abd Allāh al-Gālib y Ahmad al-Manșūr, tuvo que suponer el desarrollo de los barrios anteriores o incluso la creación de nuevos ${ }^{26}$. Sin embargo, esta expansión urbana tuvo que coexistir con grandes superficies intramuros, libres u ocupadas por huertas tal y como se puede ver en la fotografía aérea de 1917.

El distrito de Bāb Dukkāla estuvo constituido por un solo barrio del mismo nombre hasta finales del siglo $\mathrm{XIX}^{27}$, cuyo núcleo primitivo se remonta al menos a la época almohade ${ }^{28}$. Al comienzo del periodo saadí, este espacio era posiblemente un terreno abandonado como resultado de la crisis urbana del siglo XIV que finalmente fue revivido con la construcción de la mezquita, los anexos y varias propiedades, así como un suministro de agua, como precisa Ibn al-Qādị $\overline{1}^{29}$. La construcción del conjunto arquitectónico permitió la inserción del sector oeste de la medina en la dinámica urbana y por consecuencia, la creación de nuevas áreas residenciales y comerciales. No sabemos cuál fue

${ }^{25}$ Navarro y Jiménez, Las ciudades de Alandalús. Nuevas perspectivas, pp. 95-123.

${ }^{26}$ Algunos nombres de barrios han sido vinculados al periodo saadí: Darb Dabāšīi, Ŷanān Ibn Šagrā, Darb Šantūf, al-Ṭāl'a, Darb al-Ṭliṭli y sobre todo los hawmät de alMuwāssīn, Bāb Dukkāla y Riyāọ al-Zaytūn, Raji, La Ville de Marrakech, pp. 237-241.

${ }^{27}$ La medina de Marrakech estuvo organizada administrativamente en distritos ( 'alam) y a su vez cada uno contenía un número de barrios (hawma). De los siete distritos (32 barrios) que contempla el plano de Larras en 1899, seis existieron en la época saadí, excluyendo el arrabal alauí de Sīdī Abū al-'Abbās, Raji, La Ville de Marrakech, pp. 237-241.

${ }^{28}$ El célebre gramático Mūsà Yalbaht contemporáneo del califa al-Manșūr fue obligado a ofrecer clases en la mezquita de Ibn al-Abkam situada en el barrio de Bāb Agmāt, porque la mezquita de Bāb Dukkāla era muy pequeña, Ibn 'Abd al-Malik al-Marrakuš̄̄, al-Dayl wa-l-Takmila li-kitābay al-Mawșūl wa-l-Șila, p. 249; Raji, La Ville de Marrakech, pp. 245-247.

${ }^{29}$ Ibn al-Qāộ̄, Al-muntaqà al-maqșūr, pp. 258-259. 
la superficie total que llegó a alcanzar este barrio, pero no debió de sobrepasar en gran medida los alrededores del complejo, puesto que hasta 1864 en el Plan Lambert se representa una isla de construcciones rodeadas de zonas libres ${ }^{30}$. El espacio comercial, se concentró a lo largo de las principales arterias y aumentaba especialmente en la cercanía de la mezquita, tal y como se puede ver en algunos sectores en la actualidad y en las fotografías antiguas (fig. 15).

El nombre atribuido al complejo arquitectónico y al barrio en cuyo corazón se sitúa, se debe a su localización en la confluencia de dos importantes vías que se dirigen hacia la puerta de Dukkāla situada en el extremo noroeste de la medina. Un primer camino (Tarīq $S \bar{l} d \bar{l}$ 'Abd al'Azizz) proviene del centro histórico conformado por los almorávides en la zona de la actual mezquita Ibn Yūsuf y un segundo camino ( $\breve{S} a r i{ }^{\text {‘ }}$ Fātima al-Zahrā'), discurre desde el centro urbano establecido más tarde por los almohades, junto a la mezquita Kutubiyya. Estas dos arterias serían los trazados más antiguos del barrio ya que se trata de las vías que se dirigen desde las dos aljamas históricas, hacia una de las puertas de la ciudad.

Sin lugar a duda, el solar sobre el que se levanta el complejo, fue elegido intencionadamente para dotar a los edificios que lo componen de una inmejorable localización, así como para revitalizar los caminos que aquí confluyen. La disponibilidad de áreas libres en el espacio triangular que delimitan las dos arterias anteriormente indicadas proporcionó al proyecto la suficiente flexibilidad para implantarse con un trazado racional. Esta disposición ortogonal con bloques paralelos estuvo condicionada por la orientación del muro de la quibla y sin tener en cuenta las alineaciones de las calles, de manera que los ejes viarios se vieron interrumpidos por las nuevas construcciones. Por esta razón la calle de Fāțima al-Zahrā' se desplazó hacia el oeste, generando un

\footnotetext{
${ }^{30}$ El núcleo principal estaba delimitado al noreste por el 'Arșat Ben al-Šablī y el 'Arșat Ihīrī, y al oeste por el 'Arșat al-Gațtịiwi (donde se construyó el Palacio de Justicia) y por el de al-Qurțubī junto a Bāb al-Rajā. Las calles (darb) más antiguas podrían corresponder con Aḥmad b. Mūsà, Sīdī Aḥmad al-Ṭāyyar, al-Ḥalfāwī, 'Arșat Ūzāl y al-Zāwiya; muchos han sido transformados y solo algunos conservan sus puertas. El barrio ha crecido tardíamente hacia el norte hasta limitar con los barrios de 'Arșat Ihīrī, el de Sīdī Abū 'Amr y el de Riyāọ al-'Arūs. Al sureste se ha subdividido en otros dos barrios diferentes 'Arșat Ibn al-Šablī y al-Ramīla. En el siglo XIX las áreas libres circundantes fueron ocupadas por numerosos $q \bar{a}$ 'ids que construyeron sus residencias con grandes áreas ajardinadas, por lo que la densidad de habitación se mantuvo baja hasta bastante tarde, Raji, La Ville de Marrakech, pp. 245-247.
} 
gran espacio abierto y giró en recodo entorno al volumen de la madraza adosada a la esquina noroeste de la mezquita. Del mismo modo, la fachada de la fuente-abrevadero se abre hacia la calle Sīdī 'Abd al-'Azīz haciendo que la alineación se adapte al edificio y originando la formación de una plazuela. Finalmente, otra traza previa parece que subyace en el tejido al sureste del complejo, donde las dependencias de servicio de la mezquita, el hammām y otras construcciones ajenas se adaptan a una alineación que podría corresponder con un itinerario secundario dentro del cruce de viarios.

\section{Descripción del complejo religioso de Bāb Dukkāla}

Tal y como se ha indicado, la mezquita está acompañada de un conjunto de edificios complementarios organizados en torno a ella, y con la que guardan la misma orientación (fig. 2). La mezquita constituye el edificio principal, tanto por sus dimensiones como por su función, y por tanto algunos de los anexos (madraza, biblioteca y sala de retiro) se adosan a ella, mientras que otros están separados y funcionan de manera más autónoma. Al noreste de la mezquita se localiza una manzana separada que está integrada por la mida ${ }^{31}$, o pabellón de abluciones, la fuente-abrevadero y una batería de tiendas y casas. En la esquina oriental de esta manzana, una construcción moderna ocupa el solar de la antigua escuela coránica, y en el extremo norte se adosan varias viviendas. La disposición de esta manzana con respecto a la fachada este de la mezquita y el baño situado al sureste, origina dos calles secundarias perpendiculares entre sí que articulan todo el conjunto.

\section{Planta general de la mezquita}

La mezquita se basa en el esquema tradicional de planta rectangular dividida en dos partes, en este caso desiguales. Una destinada a la sala de oración de naves paralelas y otra al patio que la precede. Las dimensiones máximas del rectángulo que delimita el interior del edificio son

${ }^{31}$ De ahora en adelante nos referiremos también a este anexo como mida, término adaptado de la voz árabe $m \bar{\imath} d \bar{a}^{\text {' }} a$, que se emplea para denominar las instalaciones con lavabos donde se realizan las abluciones. 


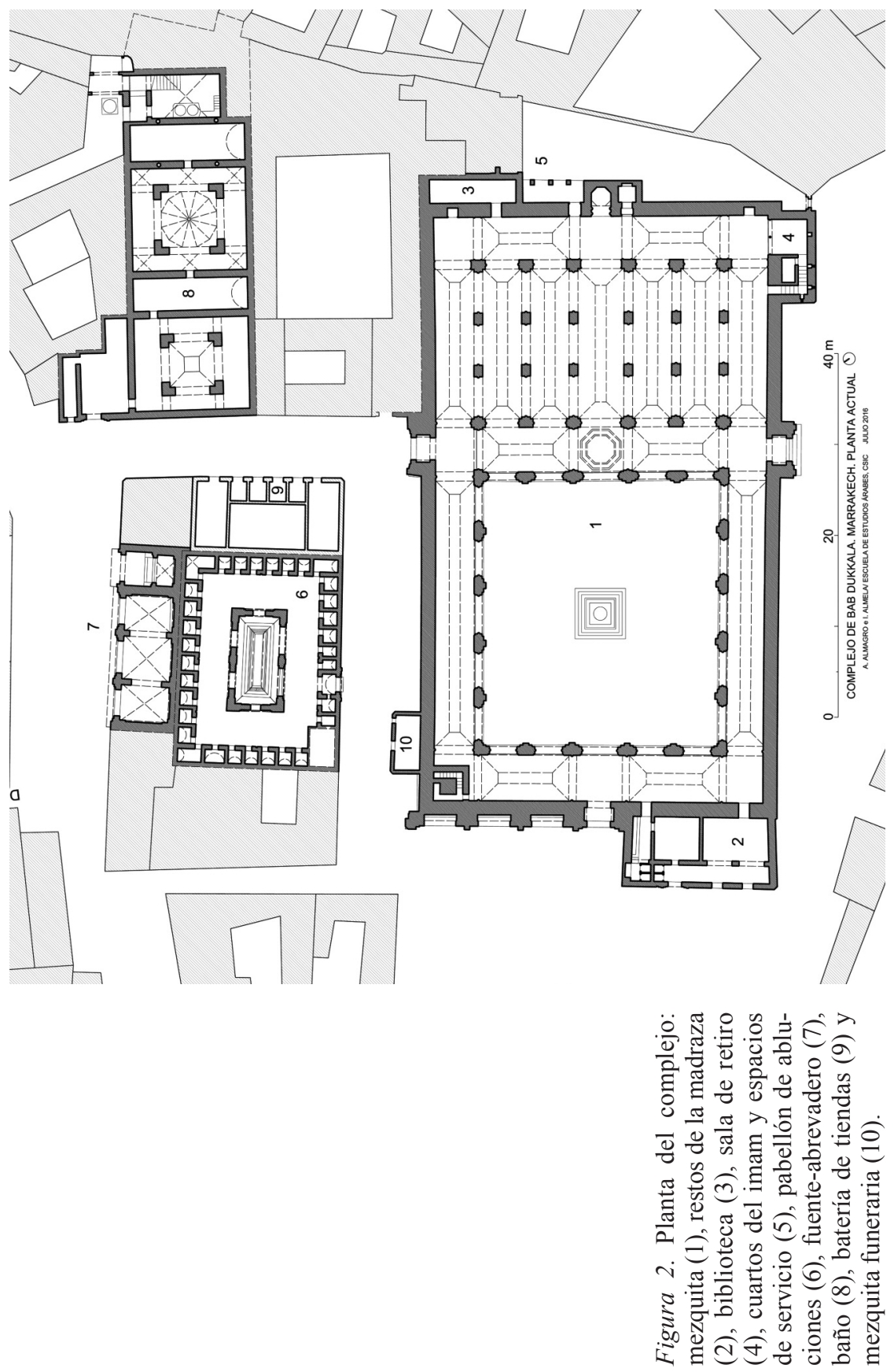

Al-Qantara XXXVIII 2, 2017, pp. 333-386 ISSN 0211-3589 doi: 10.3989/alqantara.2017.011 
aproximadamente $64 \times 36 \mathrm{~m}$, mientras que el patio casi cuadrado inscrito en él mide $29 \times 25 \mathrm{~m}$.

La sala de oración está dividida en tres partes por medio de dos pórticos, los cuales generan dos naves transversales a norte y a sur respectivamente. Ambas dejan en el medio un gran espacio dividido en siete naves paralelas con dirección perpendicular al muro de la quibla. Las naves, unas con otras conforman una malla de $5 \times 7$ módulos que estructuran la sala de oración, y en la que destaca la nave axial o central de mayor anchura $(5,06 \mathrm{~m})$ frente a $10 \mathrm{~s} 4,26 \mathrm{~m}$ de las otras seis paralelas. De las dos naves transversales, la primera está situada junto al muro de la quibla, y la segunda conforma el pórtico meridional del patio. Esta disposición se basa en el esquema tradicional en T de las mezquitas almohades, en las que la nave central y la nave yuxtapuesta al muro de la quibla toman un mayor protagonismo espacial y ornamental. Además, éstas conforman en su intersección el lugar preeminente de toda la sala de oración, es decir, la macsura o espacio reservado frente al mihrab (fig. 3). La segunda nave transversal con la que cuenta esta mezquita constituye una aportación al modelo almohade y funciona a modo de nártex entre el patio y la sala de oración. Además resalta el eje compuesto por las dos puertas laterales del templo y la puerta central del patio, donde se ubica la 'anaza $a^{32}$.

Destaca el tratamiento espacial, constructivo y decorativo que reciben los nódulos formados por la intersección de los principales ejes. Se trata, en realidad, de 6 qubbas (fig. 4) localizadas en las dos naves transversales y el pórtico septentrional del patio (en el centro y en los dos extremos de cada una de ellas). De esta manera quedan ensalzados los principales puntos de la sala de oración (la macsura, la 'anaza y las tres puertas exteriores) manteniendo una simetría volumétrica en todo el edificio (fig. 4).

\footnotetext{
${ }^{32} \mathrm{La}$ 'anaza o 'anza es un término que se sigue usando en Marruecos para referirse a una estructura situada en el vano central que da paso desde el patio a la sala de oración, de tal modo que representa un mihrab externo y sirve de referencia a las personas que rezan en el patio. Puede ser un simple retalle en el pavimento, una estructura de madera cerrando el vano, o incluso pueden emplearse ambas soluciones a la vez. En el caso de Bāb Dukkāla cuenta con una señal en el pavimento y una carpintería moderna, que posiblemente reemplazó a otra más antigua, v. Miles, " 'Anaza” en EI'; Elkhammar, "Le mobilier des mosquées médiévales du Maroc d'après les sources textuelles”, pp. 79-94.
} 


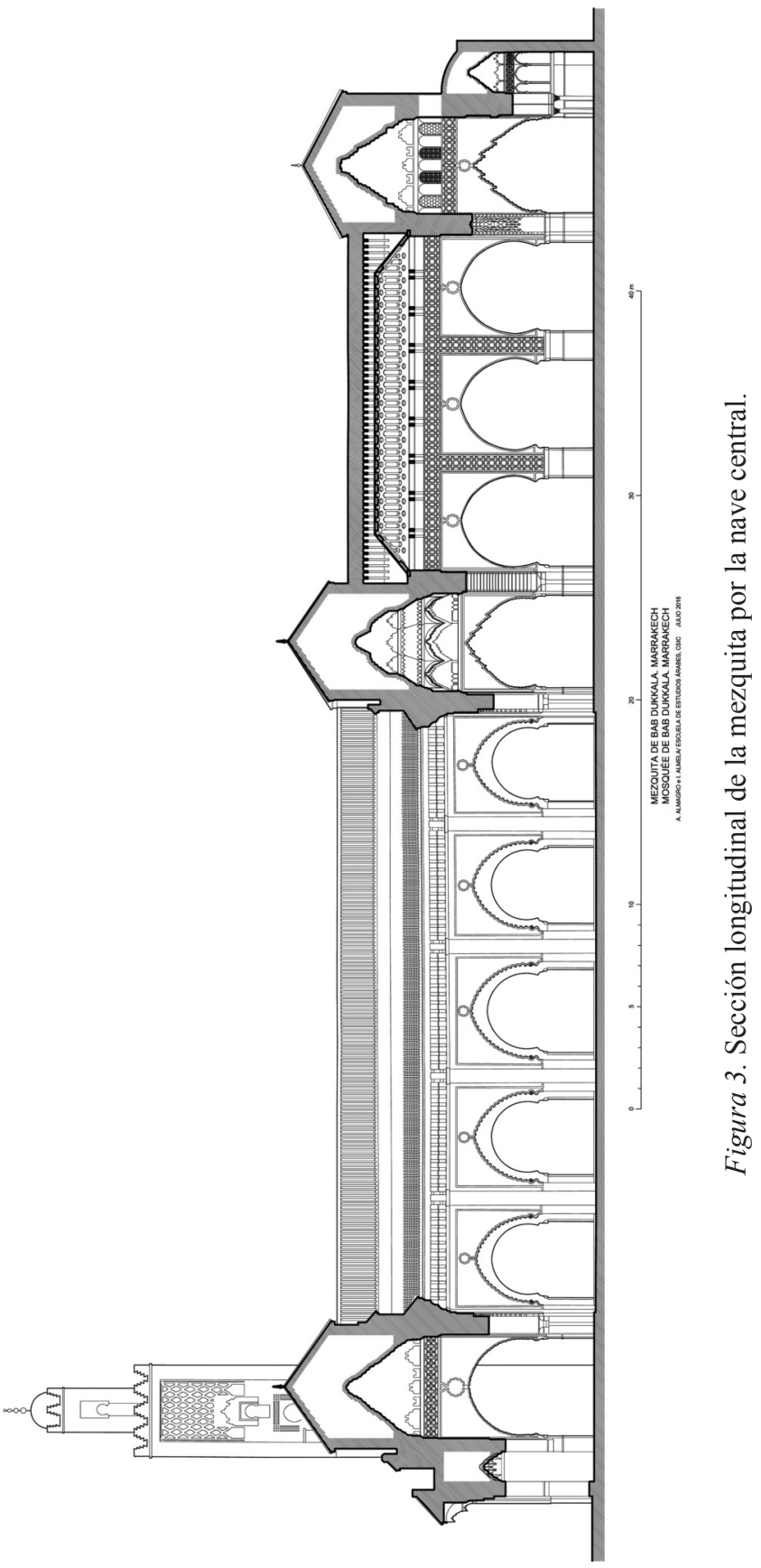




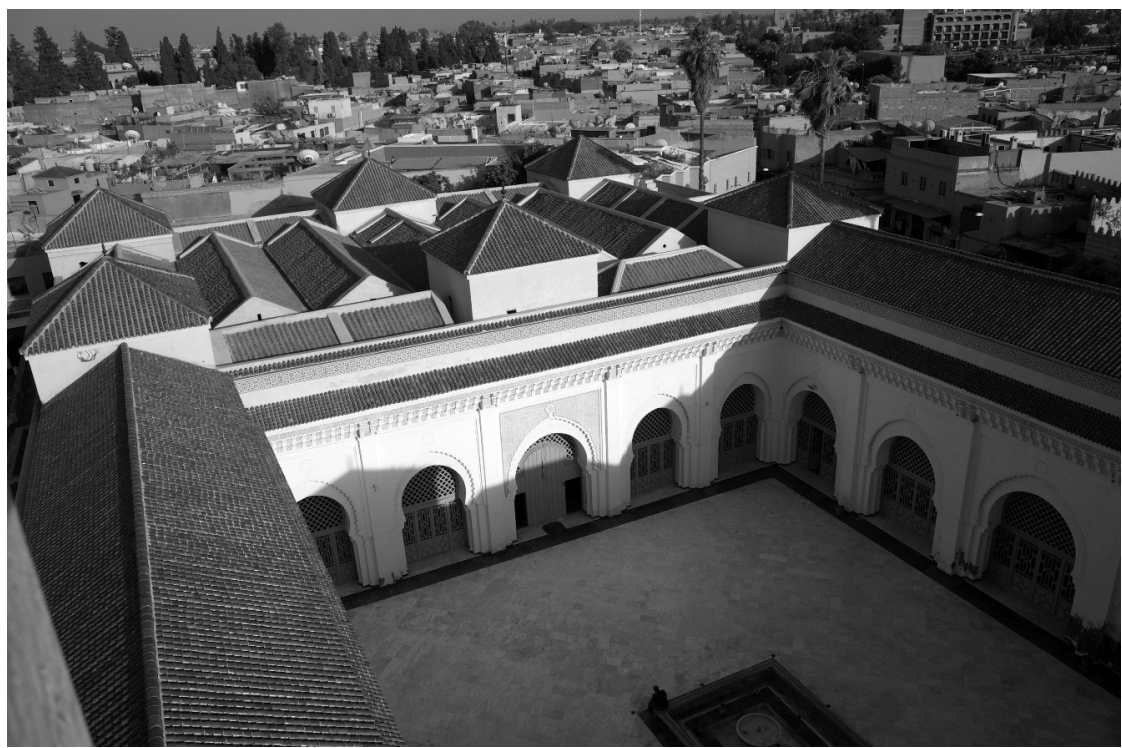

Figura 4. Vista general de las cubiertas de la mezquita desde su alminar.

Las naves laterales de la sala de oración se proyectan hacia el norte y junto con otra crujía perpendicular, delimitan un patio cuadrangular de cinco vanos en cada lado. En el centro de esta última crujía septentrional que cierra el edificio, se localiza de nuevo una qubba que realza el eje principal longitudinal y la localización de la puerta principal. Siguiendo la composición de la sala de oración, se cubre el extremo occidental de la nave con una cúpula, aunque no se extiende por simetría al extremo opuesto ya que es donde se alza el alminar.

\section{La macsura y el mihrab}

En la intersección de la nave principal con la nave transversal de la quibla, se localiza el espacio preeminente del edificio. Este espacio está delimitado: a norte por el muro de la quibla, al sur por el pórtico paralelo al mismo, y a este y oeste por dos arcos laterales (fig. 5). Todos ellos conforman un espacio de planta aproximadamente cuadrada que 


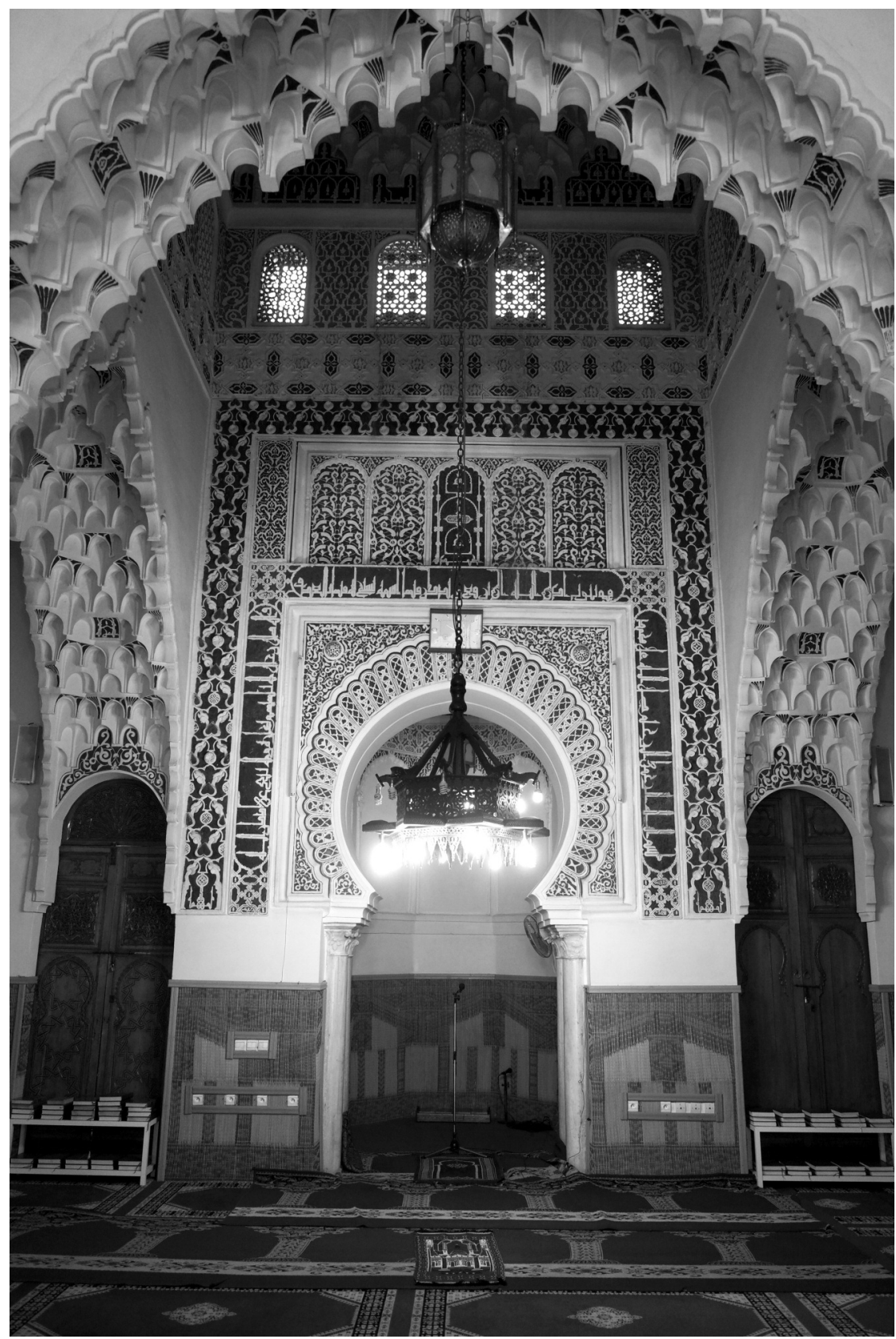

Figura 5. Imagen de la fachada del mihrab.

Al-Qanțara XXXVIII 2, 2017, pp. 333-386 ISSN 0211-3589 doi: 10.3989/alqantara.2017.011 
se proyecta en altura $(12,38 \mathrm{~m})$. El nicho del mihrab se abre en el punto medio del muro de la quibla y presenta un espacio de 3,22 m de profundidad, que se proyecta hacia el exterior con forma de espacio satélite. Su planta es de fondo ochavado con dos paredes laterales paralelas y perpendiculares al arco de entrada. En su interior, posee una nacela a 1,95 m de altura sobre la que se apoya una arquería ciega de yeso con arcos polilobulados y albanegas decoradas con sebka y motivos vegetales ${ }^{33}$. Por encima de la arquería corre horizontalmente una banda de $36 \mathrm{~cm}$ con un trazado geométrico, sobre la que descansan dos trompas planas que permiten que el nicho adopte en la parte superior una planta octogonal. Esta base poligonal sirve de apoyo para una cúpula de mocárabes cuya clave alcanza los $6,12 \mathrm{~m}$.

El vano del mihrab está integrado en una portada simétrica profusamente decorada que se exhibe hacia la sala de oración y que constituye la composición más importante desde el punto de vista ornamental (fig. 6). En líneas generales sigue el esquema de los ejemplos almorávides y almohades, los cuales hunden sus raíces en el diseño del mihrab de al-Hakam II en Córdoba. El arco de herradura apoya sobre impostas sostenidas por columnas de mármol empotradas en las jambas con capiteles de talla clásica ${ }^{34}$. El arco queda enmarcado por un primer alfiz con sección de escocia y bocel consecutivos que a su vez está abrazado por otro alfiz en U. En sus tres lados cuenta con epigrafía cúfica de gran tamaño organizada en cartuchos que en las esquinas y extremos forman entrelazados geométricos ${ }^{35}$. Cuenta con un fondo de ataurique poco visible, debido a la pintura aplicada en las últimas intervenciones. La rosca del arco se encuentra dovelada con alternancia de motivos decorativos distintos en sus dovelas y queda envuelta por un extradós formado por un arco de lóbulos. Las albanegas cuentan con un tupido

${ }^{33}$ Según Raji Elillah esta nacela contaba con una inscripción cursiva con las aleyas 75 y 76 de la azora 22 (al-haŷŷ), Raji, La Ville de Marrakech, p. 116. Según Rasha Alí se trataba de las aleyas 77 y 78 de la misma azora, Ali, L'Épigraphie, p. 205. Actualmente no existen tales inscripciones.

${ }^{34}$ Conocemos por las fuentes y por otros edificios saadíes que se importaron columnas y otras piezas de mármol desde Italia, al-Ifrān̄̄, Nozhet-Elhâdi, p. 159, trad. p. 260.

${ }^{35}$ Se trata de la basmala y la tașlīya seguida de las aleyas 36 y 37 de la azora de la luz. Esta fórmula está presente en todos los mihrabs saadíes que hemos podido estudiar hasta el momento. Deverdun también la documentó en el caso de la mezquita almohade de la Qașba, donde forma parte de la decoración resultado de la reforma saadí que se llevó a cabo en esta mezquita en época de 'Abd Allāh al-Gālib (Deverdun, Marrakech, p. 54). 


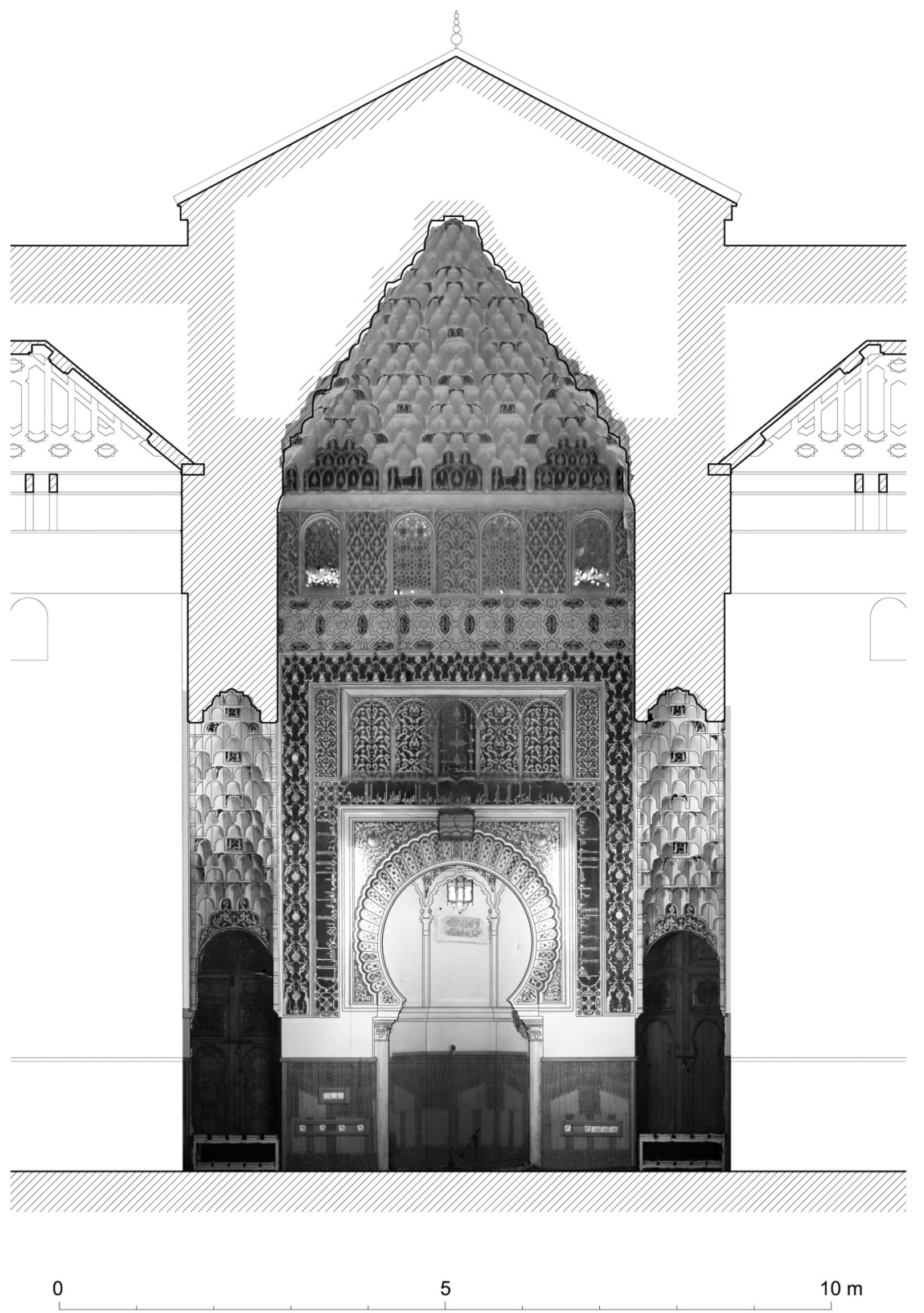

Figura 6. Sección por la macsura con el alzado del mihrab. Al-Qanțara XXXVIII 2, 2017, pp. 333-386 ISSN 0211-3589 doi: 10.3989/alqantara.2017.011 
ataurique de varios tallos espirilíneos con palmetas lisas y pimientos dispuestos en distintos planos que se entrelazan. Sobre los centros de cada albanega sobresalen sendos tondos.

Sobre la parte horizontal del alfiz epigráfico hay una banda de 1,27 $\mathrm{m}$ de altura, compuesta por paneles decorativos en los extremos y una secuencia de cinco arquillos polilobulados enmarcados por un bocel. Todos los fondos han sido decorados con ataurique, salvo el del arco central que cuenta con un caligrama arquitectónico con la jaculatoria "loor a Dios" (al-hamdu li-Llāh) en cúfico y un cartucho integrado en ella con la frase en cursiva "loor a Dios por su beneficio" (al-hamdu li-Llāh 'alà ni 'ami-hi). Toda la composición hasta ahora descrita vuelve a estar enmarcada por un tercer alfiz en el que se entretejen una malla de sebka vegetal con pares de piñas en los cruces, con otra malla lobulada que arranca de un caligrama cúfico en espejo "ventura" (yumn). Sobre la parte superior de este alfiz se localiza una banda geométrica con estrellas de ocho puntas, y sobre ella una banda en la que se alternan arcos de medio punto ciegos y otros con paneles calados que permiten la entrada de luz a través de la trama geométrica. Finalmente, una cornisa con forma de nacela remata los cuatro lados de la qubba sobre la que arrancan diferentes paneles de arcos mixtilíneos que sirven de inicio a las primeras adarajas de la cúpula de mocárabes. En dichos paneles encontramos labor de epigrafía cúfica con "la soberanía es de Dios" (al-mulk li-Llāh) y "la permanencia es de Dios" (al-baqā'li$L l \bar{a} h)$ en los paneles de las esquinas; "loor a Dios" (al-hamdu li-Llāh) en los centrales y "gracias sean dadas a Dios" (al-šukr li-Llāh) en los intermedios ${ }^{36}$.

Dentro de la composición quedan incluidas dos puertas, una a cada lado del nicho y situadas bajo los apoyos de los arcos laterales que conforman el espacio. La abertura derecha sirve para ocultar el almimbar, mientras que la izquierda sale a unas habitaciones de servicio para el imām tras el muro de la quibla. Los tres lados que cierran la qubba en torno a la portada del mihrab están cubiertos por arcos de lambrequines siendo los más ricos de toda la mezquita. El trazado base está compuesto por varios tramos con diferentes curvaturas, sobre los que se apoyan los lóbulos, arquillos y festones. En todo el ancho de sus sofitos, cuelgan mocárabes coronados en la parte superior con una estrella de

${ }^{36}$ Ali, L'Épigraphie, pp. 208-211. 
ocho puntas y una pequeña cúpula gallonada ${ }^{37}$. El arco que separa la macsura y la nave central cuenta además en sus jambas con caligramas arquitectónicos a la voz de "no hay dios sino Dios" (lā ilāha illā Allāh) (jamba izquierda) y "no hay vencedor sino Dios" (lā gāliba illā Allāh) (jamba derecha) en cúfico e integrando un cartucho con la segunda parte de la profesión de fe en cursiva ${ }^{38}$.

\section{Los pórticos interiores y las cúpulas}

Las naves perpendiculares a la quibla están separadas entre sí por pórticos de tres vanos, los cuales consisten en arcos de herradura apuntados que descansan sobre sólidos pilares de ladrillo con columnas adosadas (fig. 7). Los arcos están enmarcados por un alfiz de yesería

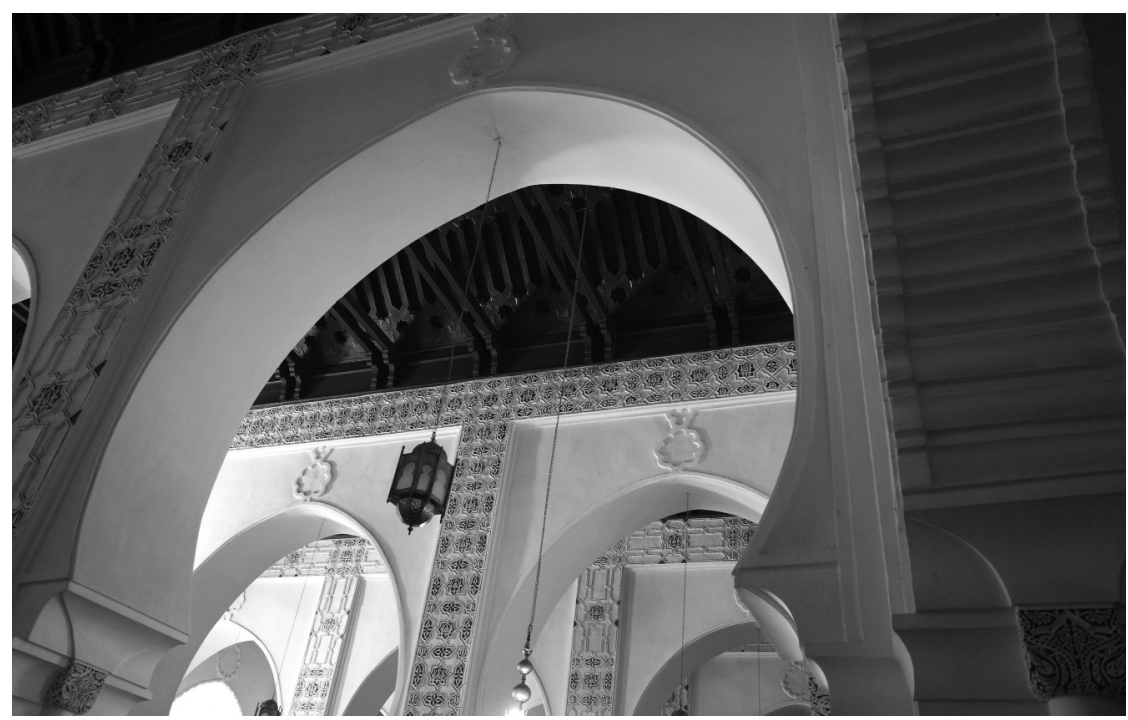

Figura 7. Imagen de las arquerías que separan las naves.

${ }^{37}$ Esta manera de enriquecer el intradós de los arcos con mocárabes, así como su empleo en torno al espacio de la macsura es una innovación almohade que encontramos en la segunda Kutubiyya, y parcialmente en Tinmal, Basset y Terrasse, Sanctuaires et forteresses almohades, p. 14.

${ }^{38}$ Ali, L'Épigraphie, pp. 187-191. 
continuo que abraza los tres arcos y que está decorado con un juego geométrico a partir de estrellas de ocho puntas. Esta decoración se vuelve más acentuada en la nave central. En la clave de los arcos unos rosetones de 8 y 12 lóbulos sirven de enlace entre el bocel que bordea el alfiz y el ribete que perfila los arcos.

Sin embargo, la homogeneidad de estas arquerías contrasta con los dos pórticos transversales que acomodan las dos naves transversales de la sala de oración (fig. 8, 9 y 10). Éstos cuentan con una mayor diversidad de arcos en cuanto a su perfil, lóbulos, arranques y geometría. Los del centro y los de los extremos son los más sublimes, con grandes arcos de base mixtilínea con lambrequines, y los arcos intermedios son angrelados. Estos últimos son de trazado apuntado con los centros de curvatura separados $3 / 5$ de la luz en el pórtico septentrional; y túmidos con los centros separados $2 / 8$ de la luz y un peralte de aproximadamente $1 / 2$ del radio en el meridional.

Como ya se ha comentado, este edificio destaca por la distribución de sus ocho cúpulas ${ }^{39}$, de las cuales tienen especial importancia las

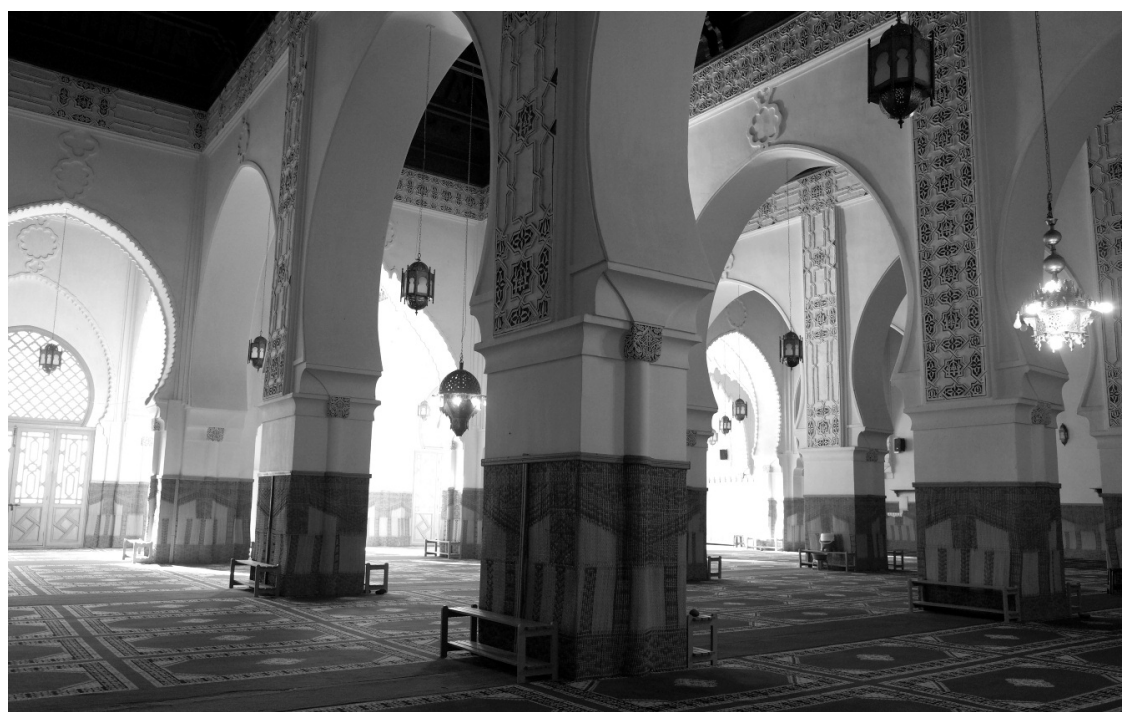

Figura 8. Vista de la sala de oración hacia el norte.

${ }^{39}$ Son ocho en lugar de nueve al estar el ángulo noreste ocupado por el alminar. 


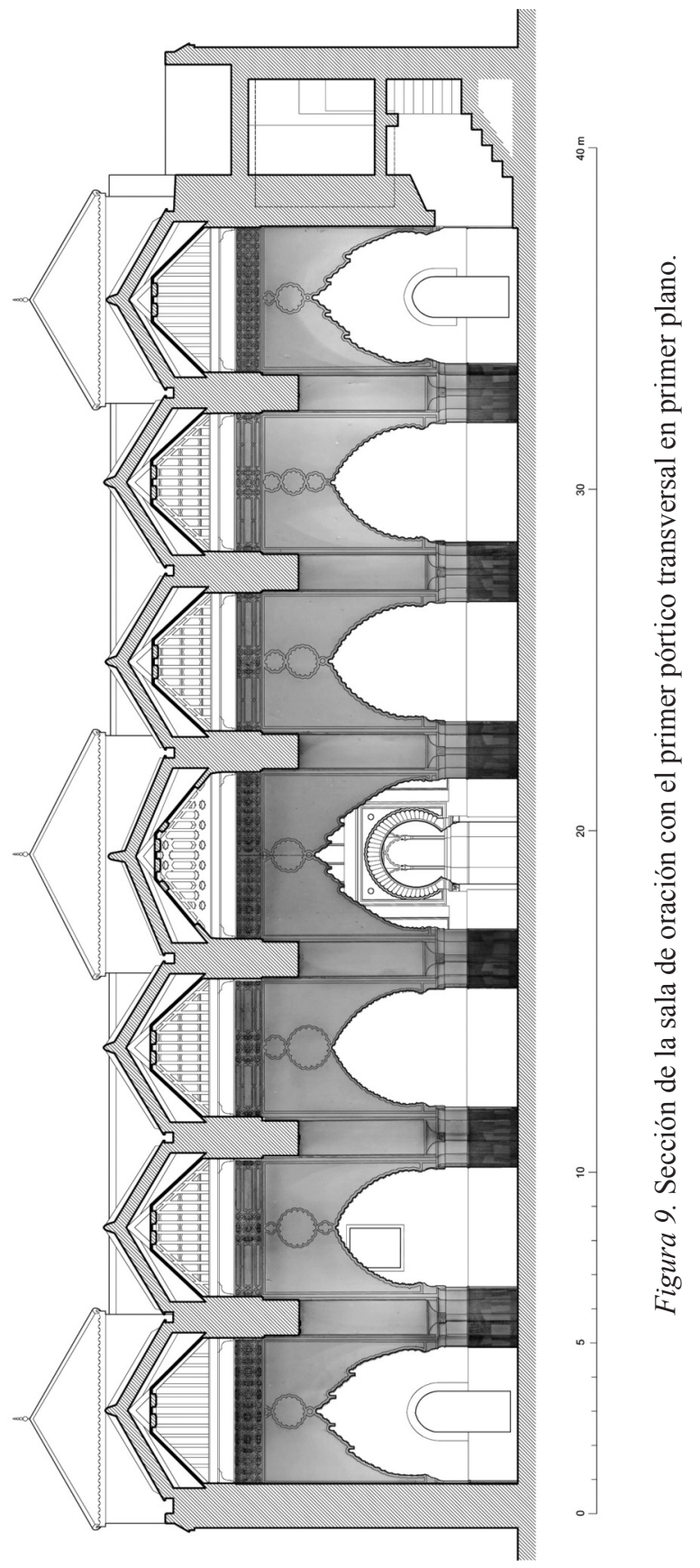

Al-Qantara XXXVIII 2, 2017, pp. 333-386 ISSN 0211-3589 doi: 10.3989/alqantara.2017.011 


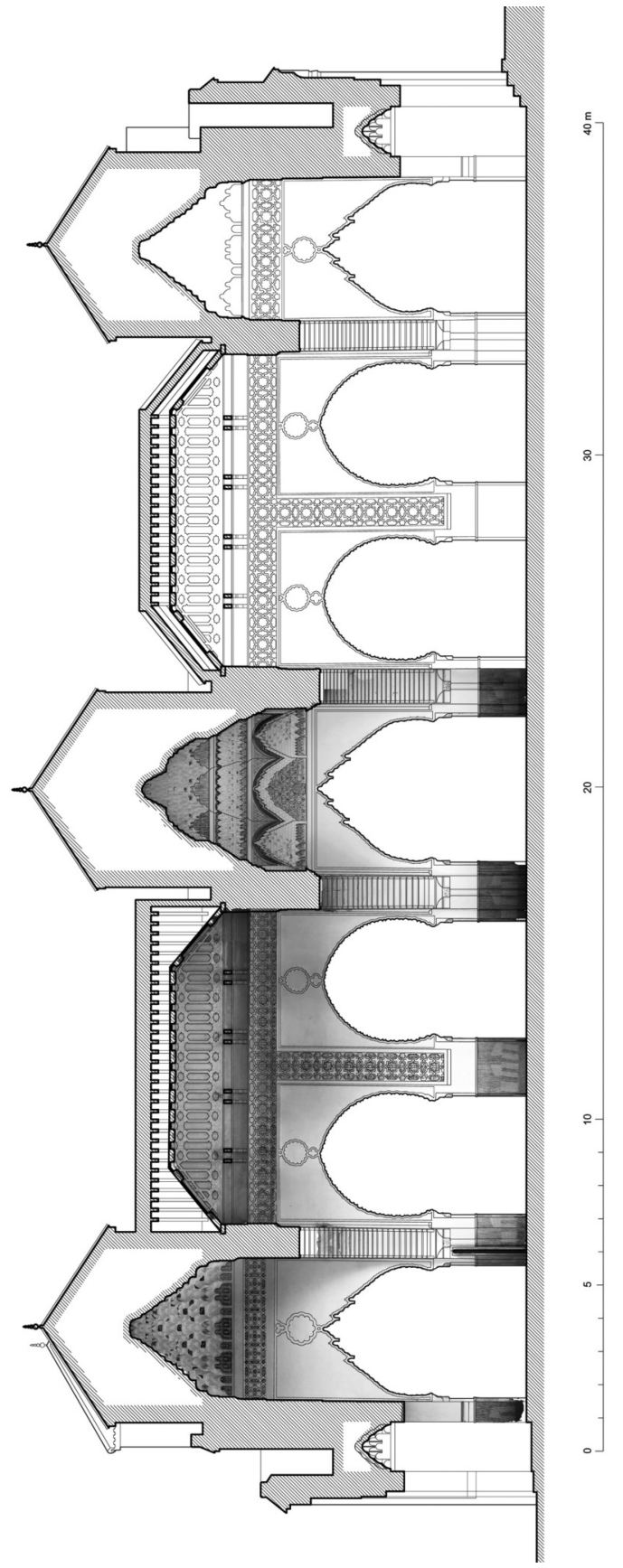

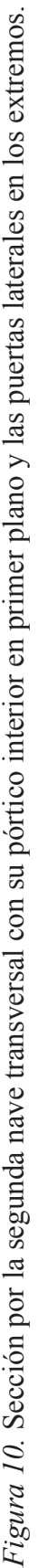

Al-Qantara XXXVIII 2, 2017, pp. 333-386 ISSN 0211-3589 doi: 10.3989/alqantara.2017.011 
tres situadas en la nave transversal junto a la quibla (siguiendo la tradición almohade) y la cúpula de la 'anaza, ampliamente difundida en época meriní. Se consigue de esta manera, destacar espacial y volumétricamente los extremos y centro de cada una de sus tres naves transversales. Consisten en cúpulas elaboradas con mocárabes de yeso y simétricas con respecto a los dos ejes (fig. 11). En algunos casos, cubren espacios no exactamente cuadrados (naves laterales), aunque su irregularidad es absorbida por las juntas de las diferentes piezas. Las cúpulas están trazadas a partir de una estrella central de ocho puntas situada en la clave, la cual se desarrolla a modo de cascada descendente con 14 o 16 hiladas de adarajas escalonadas, entre las cuales se sitúan dos niveles de mesetas coronadas con pequeños cupulines. En las superficies curvas de sus adarajas, aparecen salteadas de forma ordenada diferentes policromías con inscripciones, elementos vegetales y gallones.

La cúpula situada junto a la puerta de la 'anaza es la que difiere compositivamente del resto, tanto por su diseño como por su altura. Ésta nace sobre una nacela situada a $6,48 \mathrm{~m}$ sobre el suelo, mucho más

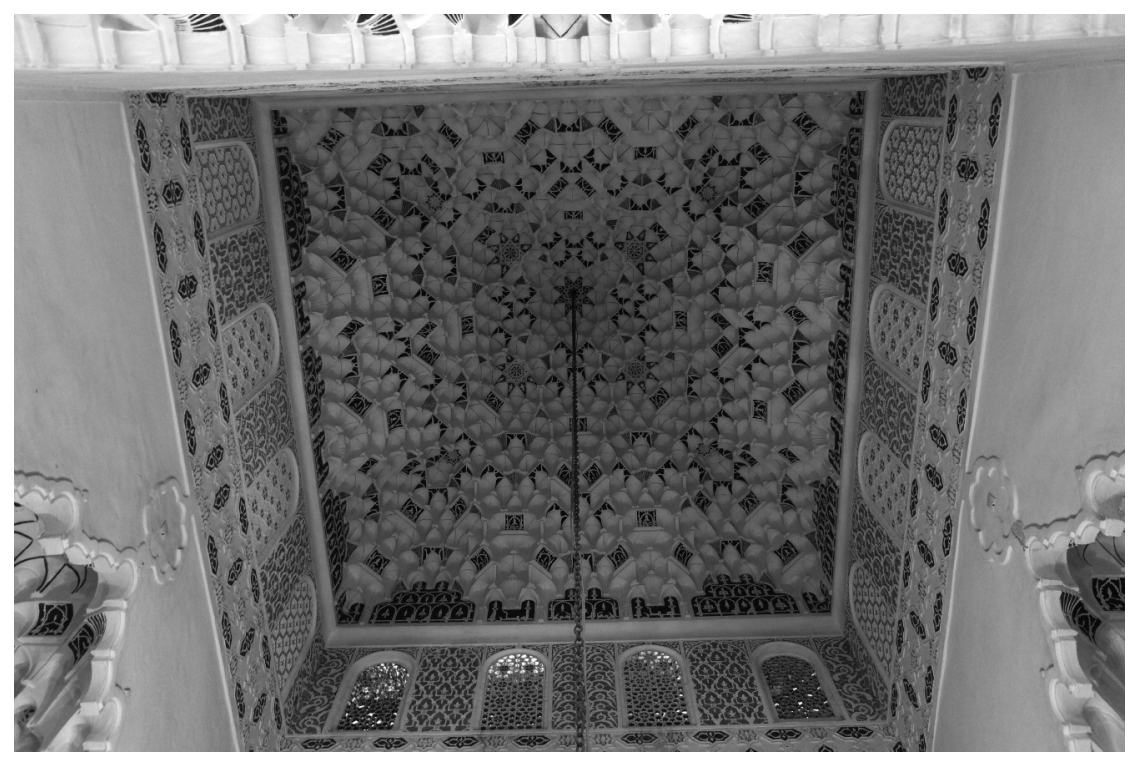

Figura 11. Cúpula de mocárabes sobre la macsura. 
baja que el resto de cúpulas, por lo que la sensación visual desde abajo simula una mayor amplitud. Está organizada en tres órdenes con una altura total de $5 \mathrm{~m}$. El primero consiste en cuatro trompas de mocárabes que permiten el paso de la planta cuadrada a la octogonal, acompañados de cuatro tímpanos cargados de ataurique. Sobre una segunda nacela se levanta el segundo cuerpo con un gran friso ochavado de mocárabes que contrae ligeramente la luz. Finalmente, una nueva nacela octogonal sirve de asiento al tercer y mayor cuerpo compuesto con 10 hiladas de adarajas y tres niveles de cupulillas intermedias. Culmina en la clave con una estrella de dieciséis puntas.

\section{El patio}

El patio cuenta con una planta aproximadamente cuadrada de 25,79 x 28,90m, cuya superficie sumada a la de sus tres pórticos, comprende más de la mitad del espacio de la mezquita (fig. 12). Está delimitado por cuatro fachadas interiores de cinco vanos, los cuales se resuelven

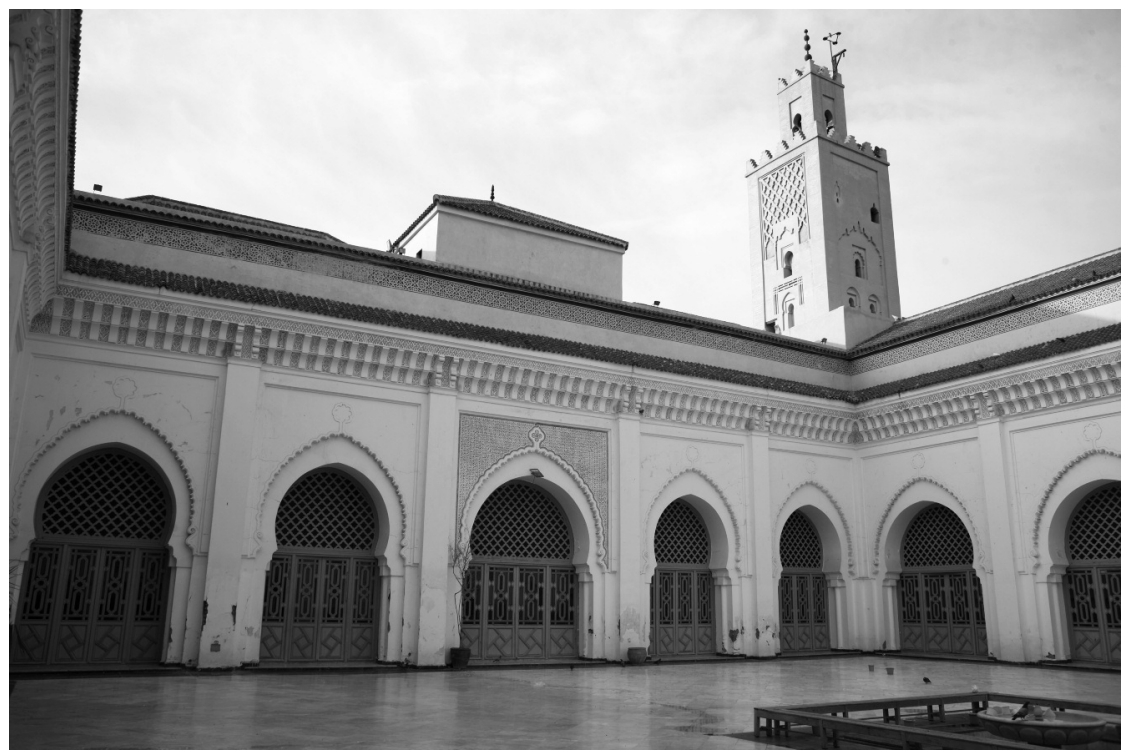

Figura 12. Ángulo noreste del patio de la mezquita con el alminar. 
de manera generalizada mediante arcos de herradura suavemente apuntados con impostas que apoyan sobre columnas adosadas a las jambas. Estos arcos son trasdosados por otro arco angrelado de base geométrica apuntada que apoya sobre motivos serpentiformes y cuenta con ribetes que se entrelazan en la clave para formar una flor. Los frentes norte y sur, se cruzan con el eje longitudinal del edificio, de manera que sus vanos centrales reciben un tratamiento más distinguido en consonancia con las qubbas interiores a las que preceden. Éstos, cuentan con una mayor luz en correspondencia con el ancho de la nave central, y están resueltos con arcos túmidos cuyos centros de curvatura se separan 2/6 de la luz con un peralte de 1/8 del radio. Además, la decoración de estos vanos es más rica en sus albanegas.

Los cuatro frentes están coronados por una cornisa perimetral situada a 7,33 m de altura, y apoyada sobre pilastras que enmarcan los vanos. Una primera nacela marca la línea horizontal sobre la que apoyan las ménsulas, las cuales se componen de dos lóbulos de manera generalizada excepto sobre las pilastras, donde se disponen pares de molduras serpentiformes. Las ménsulas alternan con metopas curvas, sobre cuya superficie se extiende una decoración a base de epigrafía cúfica y motivos vegetales, aunque por su aspecto no podemos saber si guardan relación con la decoración original. Las carpinterías que cierran todos los vanos son de factura muy simple y fueron elaborados en $1970^{40}$.

\section{Las armaduras y cubiertas de las naves}

Exceptuando los módulos coronados con cúpulas de mocárabes, el resto del edificio está cubierto con armaduras de carpintería. Se trata de estructuras compuestas de pares y nudillos con limas moamares en las aristas y dobles tirantes espaciados cada cinco calles. El arrocabe comienza por encima de un friso de yesería decorado con motivos geométricos y está compuesto por tres tocaduras, con las que se alternan dos aliceres. En el superior entestan los tirantes mientras que, en el inferior de mayor altura, lo hacen las ménsulas para reducir la luz libre de flexión.

\footnotetext{
${ }^{40}$ Una lápida de mármol situada junto a la puerta principal deja constancia de las obras de restauración que realizó el rey Hasan II en 1970.
} 
Sin embargo, hallamos en el edificio dos diseños distintos. Por un lado, el más elaborado se localiza en las zonas nobles, es decir, en las dos naves transversales y en la nave axial. Cuentan con peinazos agramilados en la parte alta y baja de los faldones, así como en la totalidad del almizate que forma una decoración de lazo de ocho. Las estrellas se disponen al tresbolillo jugando con nudos como ocurre en la armadura de la Sala Regia del Generalife y en la Sala de la Fundadora del Convento de Santa Clara la Real de Toledo ${ }^{41}$. Sobre el alicer superior corre una tocadura sin arjeute. El segundo tipo cubre el resto de naves y presenta peinazos parecidos a los otros pero únicamente en el almizate. En los faldones, las calles están cubiertas con labor de menado de cintas y alfardones hexagonales alargados. En el encuentro de los faldones con los estribos, se cubren los huecos descubiertos de las calles con tabicas verticales fijadas a los pares.

Para todas las armaduras de la sala de oración, se ha empleado de forma generalizada el mismo ancho de almizate con su correspondiente apeinazado, de manera que lo que varía de unas naves a otras, es la largura e inclinación de los faldones. Suponemos que los pares se entregan en barbilla al estribo para transmitir y repartir el peso a los muros, así como el empuje horizontal a los tirantes. Asimismo, creemos que están unidos entre sí mediante horquilla sin hilera, tal y como se pudo observar en la otra gran mezquita saadí de al-Muwāssīn, la cual presenta armaduras parecidas.

Aunque no se ha podido observar in situ, creemos que las cubiertas están compuestas, al igual que en esta otra mezquita saadí, por dos envolturas. La interior conformada por las armaduras ya descritas; y la sobrecubierta exterior, que consistiría en faldones apoyados en la cumbrera de la armadura inferior y muretes recrecidos en los laterales (técnica conocida localmente como tanfij). Esta segunda piel favorece la conservación de la armadura ante posibles defectos de impermeabilización de la cubierta superior de teja y además genera una pequeña cámara que permite la ventilación y secado en caso de haberse humedecido.

De haber existido, no se observa policromía ni decoraciones talladas en el arrocabe, así como tampoco en los pares, nudillos, tirantes o alfardones. Las armaduras han sido repintadas en las recientes intervenciones por lo que no podemos saberlo.

${ }^{41}$ Nuere, Carpintería de armar española, p. 79. 


\section{El alminar}

En la esquina noreste de la mezquita, ocupando gran parte del espacio cuadrangular que resulta de la intersección entre los pórticos norte y este del patio, se sitúa el alminar. Tiene forma prismática con planta cuadrada de 4,62 m de lado y 21,36 $\mathrm{m}$ de altura (respetando la proporción habitual de cinco veces la base) y se remata en lo alto con almenas escalonadas. La torre construida enteramente con ladrillo, cuenta con una escalera de planta cuadrada que sube girando en sentido antihorario alrededor de un gran machón central macizo. Los tramos se cubren por medio de bóvedas que se van escalonando. Sobre este primer cuerpo, sobresale otro de menores dimensiones, $2,15 \mathrm{~m}$ de ancho y sobresale $4,28 \mathrm{~m}$ por encima del primero para alojar la escalera de salida a la terraza superior, que se dispone atravesando el machón en el eje norte-sur. Los cuatro frentes del alminar se ornamentan siguiendo una composición habitual en el Occidente islámico que sigue especialmente los recursos empleados por los almohades para este tipo de construcciones. En cada una de las cuatro fachadas, hay un gran recuadro rehundido cargado con composiciones y decoraciones diferentes. En los alzados este y oeste predomina un gran paño de sebka que arranca de arquillos ciegos mixtilíneos sobre columnillas, en el que se integran varios arcos de herradura y lobulados. En cambio, en los alzados norte y sur predominan los grandes arcos mixtilíneos en relieve, así como los vanos con arcos lobulados y de herradura. El cuerpo de la linterna posee el mismo tratamiento en sus cuatro alzados visibles con un pequeño arco túmido con alfiz rehundido. En su coronación se encuentra rematado con una pequeña cúpula ochavada sobre trompas, en la que se alza un $\hat{y} \bar{a} m \bar{u} r$ de cuatro esferas.

Sin embargo, algunas irregularidades en relación con la mezquita dan la impresión de que la torre fue construida posteriormente. Como ya se ha indicado, la torre está levantada en la esquina noreste del patio, invadiendo un espacio cuadrangular que resulta de la intersección de dos de sus pórticos. Precisamente esta mezquita se caracteriza por acentuar volumétricamente en altura todas las esquinas y cruces de sus ejes mediante cúpulas de mocárabes, siendo este el único nódulo de todo el edificio que no cumple con ello. De acuerdo con dos indicios que permanecen podemos interpretar que efectivamente el alminar no estuvo planificado inicialmente. En primer lugar, subiendo por su escalera encontramos sobre los dos muros perimetrales de la mezquita, los 
restos de un friso de yesería (fig. 13) que corresponden con el elemento decorativo que recorre la parte superior de la sala de oración. Esto demuestra que la zona que ocupa el alminar fue decorada como el resto de la mezquita y que por tanto la construcción de éste no estuvo proyectada en origen. Además, la factura de estas yeserías es semejante a las del oratorio aunque no han sido repintadas, lo que revela que todo el conjunto ornamental podría corresponder al primer momento de construcción. En segundo lugar, al observar las fachadas exteriores norte y este, podemos ver como el alminar emerge por encima de un cuerpo mayor en planta, que bien podría haber pertenecido al tambor cuadrado planificado originalmente para cubrir el espacio con una cúpula. La identificación de estructuras que pudieron corresponder a una segunda fase coincide con el planteamiento histórico de que las obras del complejo fueron retomadas por la madre de al-Manșūr.

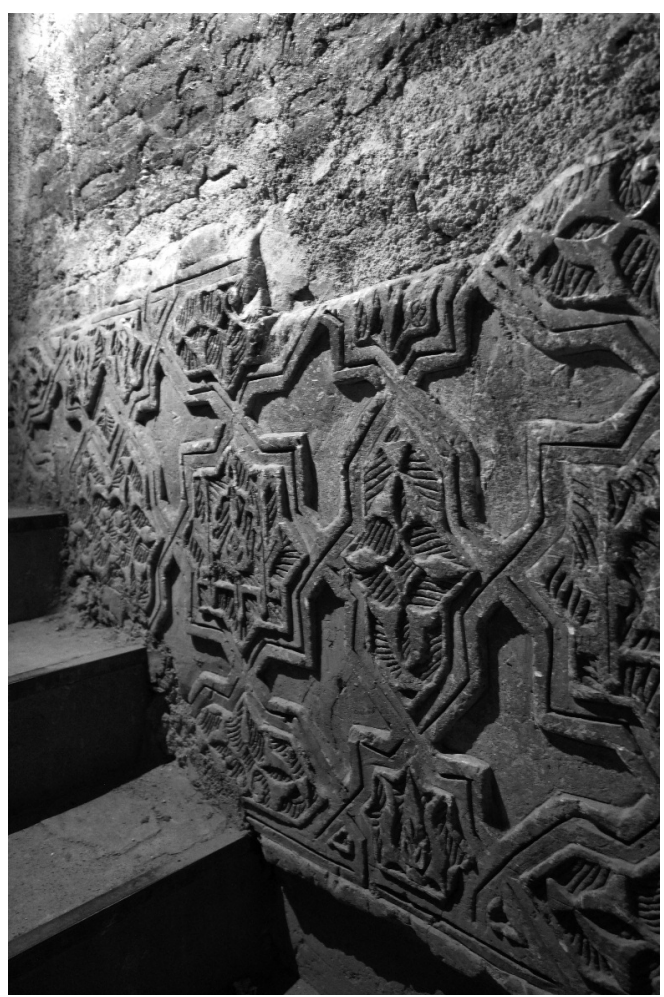

Figura 13. Detalle del friso que se conserva en el interior del alminar. 


\section{Las fachadas exteriores y las puertas}

El hecho de que el barrio no se haya densificado totalmente y se haya mantenido en gran medida el espacio público circundante a la mezquita, han hecho que actualmente dos de sus fachadas y parte de otra sigan visibles y formen parte de las calles y espacios circundantes. El volumen de la mezquita puede leerse de manera continua en casi todo su perímetro. Consiste en un prisma rectangular descrito por muros exteriores de 10,50 $\mathrm{m}$ de altura aproximadamente y coronados con un remate de tejas. Sobre este prisma sobresalen en altura las cubiertas y el alminar, al mismo tiempo que a su alrededor se proyectan las puertas y se adosan otros volúmenes menores como la madraza y la sala de retiro.

La puerta principal de la mezquita está abierta en la fachada norte coincidiendo prácticamente con el eje de la calle de Bāb Dukkāla; la oriental se abre a las calles secundarias generadas por los anexos del complejo, y la occidental permite el ingreso desde el espacio abierto por el que discurre la vía Fāțima al-Zahrā'. Las tres puertas están resueltas del mismo modo mediante un vestíbulo que sobresale en la fachada, y cuyo interior lo cubre una bóveda de mocárabes con remate de doble cupulín ${ }^{42}$.

La puerta principal se alza en el medio de la fachada norte (fig.14) y está engalanada con un tejaroz sobre dobles zapatas y canecillos finamente tallados. En la mitad occidental de este mismo alzado, se adosa la madraza con un volumen más bajo, mientras que en la mitad oriental, se adosa una carcasa de 8,11 m de altura y 1,68 m de espesor compuesta por tres vanos ciegos que no llegan hasta el suelo ${ }^{43}$. Este falso pórtico con arcos de herradura trasdosados por arcos lobulados, es muy parecido al que rodea la mezquita al-Muwāssīn, aunque en el caso vecino son ligeramente más profundos y albergan espacios útiles internos. Podemos localizar un ejemplo de esta solución de fachada en los restos conservados del frente oriental de la primera Kutubiyya, así como en las fachadas septentrional y occidental de la mezquita de la

42 Esta misma solución la encontramos en la Puerta del Lagarto de la Catedral de Sevilla y es una reminiscencia de la mezquita aljama de época almohade. Almagro, "Jardín con plantas (y alzados) de papel”, pp. 242-243.

${ }^{43}$ Las arcadas fueron cegadas con tapial, tal y como puede verse en la fotografía de Herbert White publicada por Meakin, The Land of the Moors, p. 293. 

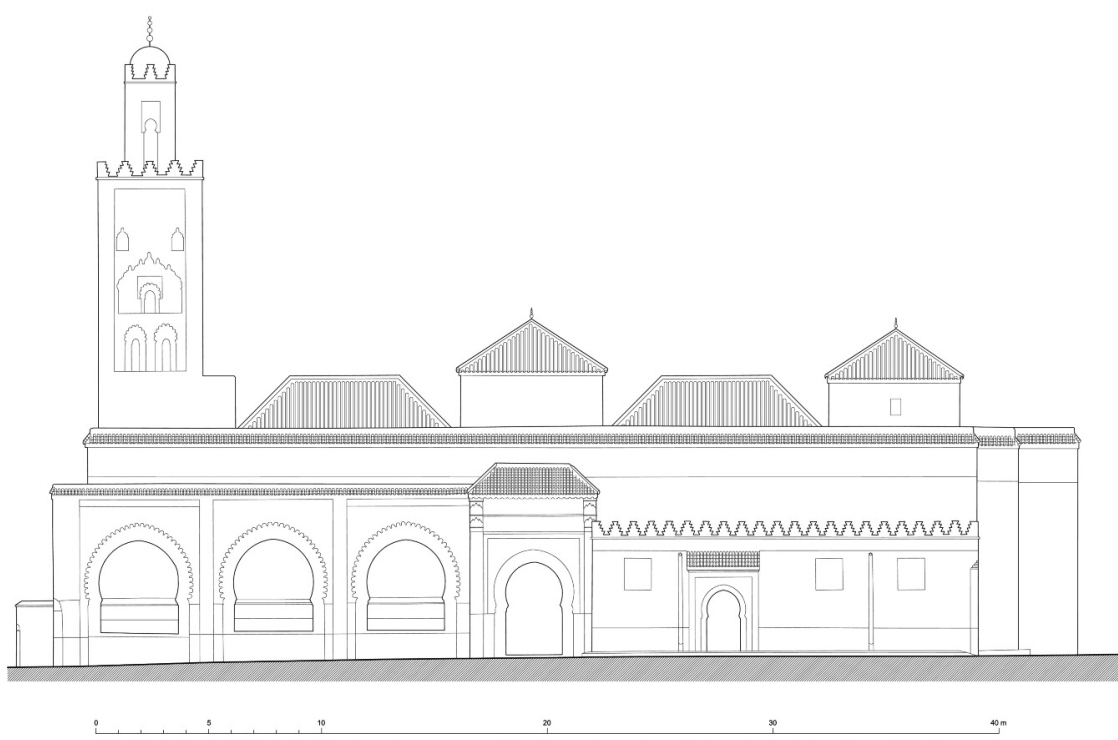

Figura 14. Fachada norte con la puerta principal, el alminar y los restos de la madraza adosados.

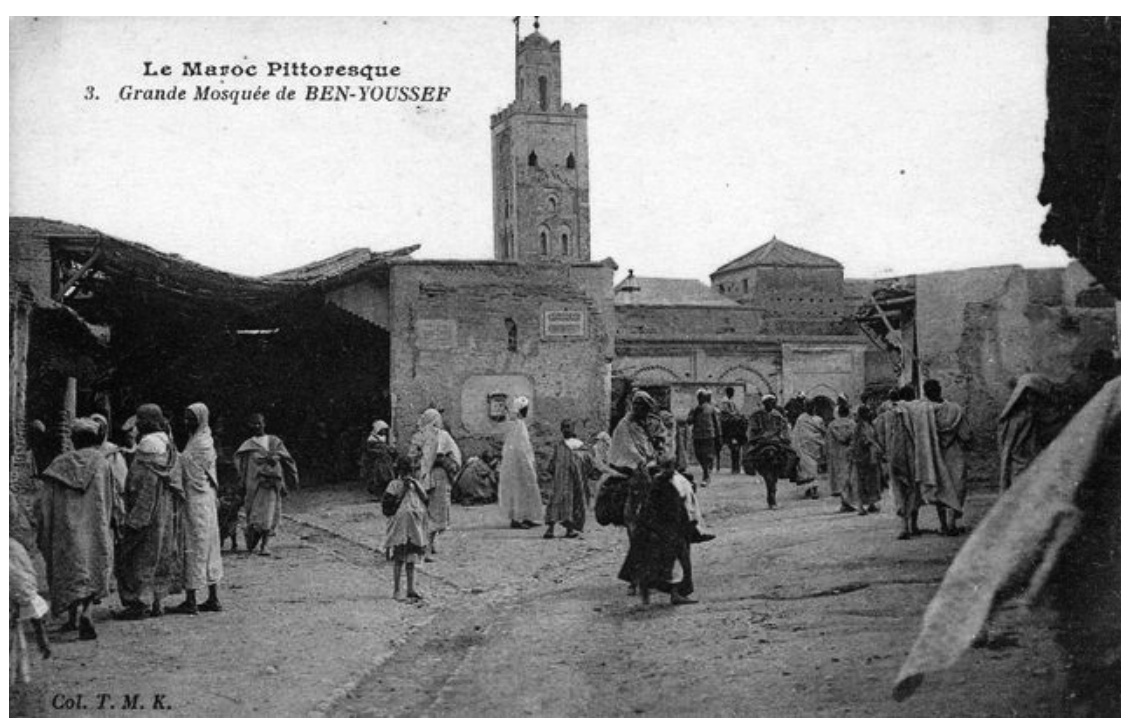

Figura 15. Foto antigua de la fachada norte desde la arteria principal del barrio. Al-Qantara XXXVIII 2, 2017, pp. 333-386 ISSN 0211-3589 doi: 10.3989/alqantara.2017.011 
Qașba. Aunque no se observa actualmente, es posible que este tratamiento exterior estuviese pensado también para la fachada oriental, ya que la pilastra del ángulo septentrional presenta huellas del arranque de arcos y alfices similares en el frente oriental.

A partir de las fotografías históricas podemos saber que las últimas restauraciones han acicalado en exceso las fachadas. Por un lado, elevaron el muro de cierre perimetral y por otro realizaron el tejaroz y la decoración de la puerta principal, hasta entonces inexistentes (fig. 15).

\section{La sala de retiro}

Junto con la biblioteca, la madraza y la mezquita funeraria son los cuatro anexos que están adosados a la mezquita, mientras que el resto de construcciones del complejo orbitan en torno a ella de manera aislada. La sala de retiro está integrada en un volumen prismático de $4 \mathrm{x}$ $10 \mathrm{~m}$ adosado al extremo meridional de la fachada oeste ${ }^{44}$. En su interior consta de dos partes: la primera está compuesta por una estrecha escalera de dos tramos en codo que abraza un pequeño habitáculo en la parte superior, mientras que la segunda es una habitación cuadrada de $3,88 \mathrm{~m}$ de lado a la que se accede por la escalera mencionada. Esta habitación se abre con un mirador hacia la nave transversal de la quibla y genera una rica portada en la sala de oración (fig. 16). Está compuesta por un vano geminado con una columna central con capitel de mocárabes y dos semicolumnas a cada lado con capiteles cúbicos de tradición meriní-nazarí que sostienen dos arcos angrelados. La sala está cubierta con un alfarje apeinazado con lazo en ocho, al igual que las armaduras de las naves. La presencia de este anexo adosado a la mezquita no es común en las mezquitas magrebíes, de hecho los dos ejemplos saadíes son los únicos que hayamos podido observar con esta disposición ${ }^{45}$.

Su decoración en yeso se concentra en el mirador abierto a la sala de oración que adopta forma de portada con dos arcos angrelados y albanegas decoradas con ataurique, todo ello enmarcado tanto al exterior

${ }^{44}$ El retiro espiritual o $i^{\prime} t i k \bar{a} f$ debe hacerse en las mezquitas, aspecto que ya aparece recogido en el Corán, Calvo, Las mezquitas de al-Andalus, pp. 250-251.

${ }^{45} \mathrm{Su}$ disposición es parecida a la de la biblioteca de la Gran mezquita de Fez, Maslow, Les mosquées de Fès et du nord du Maroc, p. 40. 


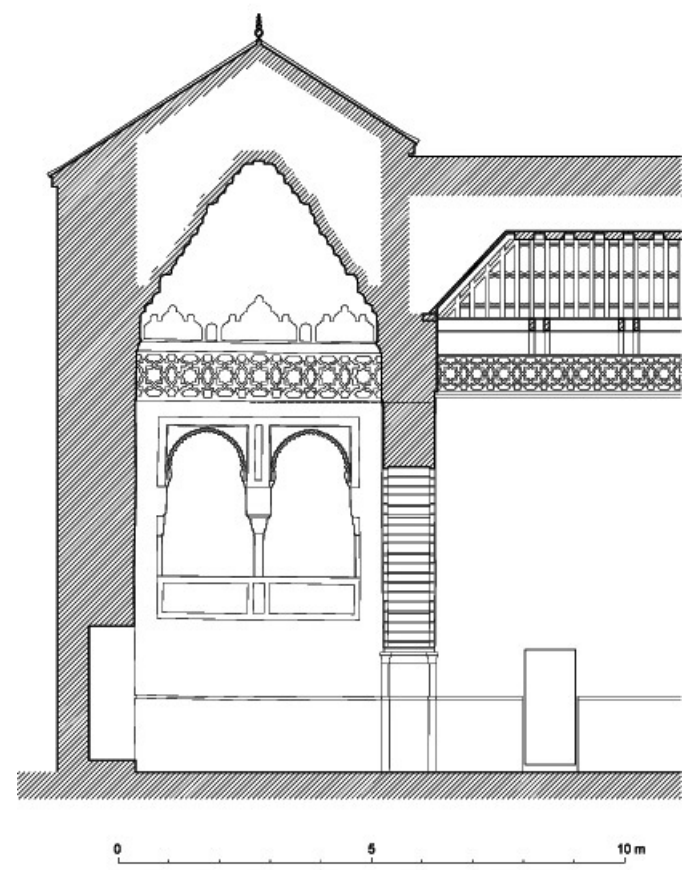

Figura 16. Alzado de la portada de la sala de retiro.

como al interior con un alfiz con decoración epigráfica cursiva que emplea la fórmula "al- 'áfiya al-bāqiya". Las otras tres paredes interiores de la sala, cuentan únicamente con una banda superior con motivos geométricos entrelazados y la misma cinta epigráfica.

\section{La biblioteca}

Este espacio, actualmente en desuso, se sitúa al sur del muro de la quibla en su extremo oriental. Se trata de un espacio de planta rectangular de 9 × 2,5 m al que se accede a través de una puerta situada en el extremo este del muro de la quibla y dispone de una ventana enrejada que abre hacia la sala de oración. El interior ha sido completamente transformado y actualmente no conserva ningún elemento original. 


\section{La madraza}

La madraza fue construida adyacente a la mitad occidental de la fachada norte de la mezquita y está considerada como una de las madrazas más conocidas de época saadi ${ }^{46}$, por lo que podemos suponer que es contemporánea a la mezquita. Desgraciadamente fue prácticamente destruida en los años sesenta y transformada en una pequeña escuela coránica. Sin embargo, gracias a una planimetría conservada en la Inspección de Monumentos de Marrakech podemos conocer su verdadera organización. En este documento, la madraza estaba provista de un acceso con vestíbulo en el muro oriental que accedía directamente a un patio rectangular de 5,60 x 11,70m rodeado por trece habitaciones. Además, contaba con una escalera que según la descripción de Deverdun accedía, con toda seguridad, a una segunda planta. Según Deverdun, parece haber sido construida al mismo tiempo que la fachada adosada al oratorio.

\section{La mezquita funeraria}

Situada al exterior del ángulo noreste de la mezquita, esta pequeña sala descubierta de 5.9 × $2.8 \mathrm{~m}$ cuenta con dos accesos, uno desde la calle de la mida y otro desde la nave lateral de la mezquita. Se trata del espacio más austero de todo el complejo, quizás como consecuencia de su función. La oración de los difuntos no se realizaba en el interior de la mezquita aljama, sino junto a sus puertas o en espacios habilitados para ello, porque según la ortodoxia musulmana el cadáver es considerado un elemento impuro y no puede estar dentro del oratorio ${ }^{47}$. En época almorávide se comenzó a habilitar un lugar especial tras el muro

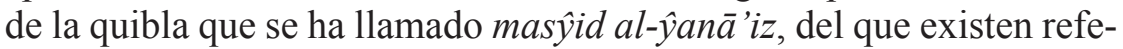
rencias y restos en al-Andalus y el Magreb al menos desde el siglo $\mathrm{XII}^{48}$. No obstante, esta modesta construcción parece haberse construido a posteriori ya que invade el espacio sobre el que estaba plani-

${ }^{46}$ Raji, La Ville de Marrakech, p. 128.

${ }^{47}$ Fierro, "El espacio de los muertos: fetuas andalusíes sobre tumbas y cementerios", pp. 153-189.

${ }^{48}$ Terrasse, La Mosquee al-Qaraouiyin a Fes, pp. 21-22, Calvo, Las mezquitas de alAndalus, pp. 167-169. 
ficado continuar la arquería de la fachada norte. Es muy probable que en origen esta función se situase tras el muro de la quibla, donde se encuentra un antiguo patio de servicio al que se puede acceder desde la mezquita por medio del vano izquierdo que flanquea el mihrab, y además cuenta con otra puerta exterior ${ }^{49}$.

\section{La fuente-abrevadero}

Se trata de uno de los anexos más importantes del complejo, dado que su construcción caritativa permitía abastecer a todo el barrio de agua. Próxima a la mezquita de Bāb Dukkāla, este anexo conforma junto con el pabellón de abluciones y varias tiendas en batería, una manzana aislada rodeada por calles. Su fachada se abre a una estrecha plaza por la que discurre la calle Sīdī 'Abd al-'Azīz generando un alzado monumental en el paisaje urbano (fig. 17). Fue restaurada por la Inspection des monuments historiques de Marrakech en 1920 y $1983^{50}$.

La tradición oral local, atribuye la construcción de este edificio al bereber Lahsen Ou Ali (al-Hasan b. 'Alī). Este alfaquí habría enseñado exegesis coránica en la mezquita, pero ignoramos en que época viviós1. No obstante, podemos datar la fuente-abrevadero como saadí, dada su integración dentro de todo el conjunto arquitectónico y su similitud

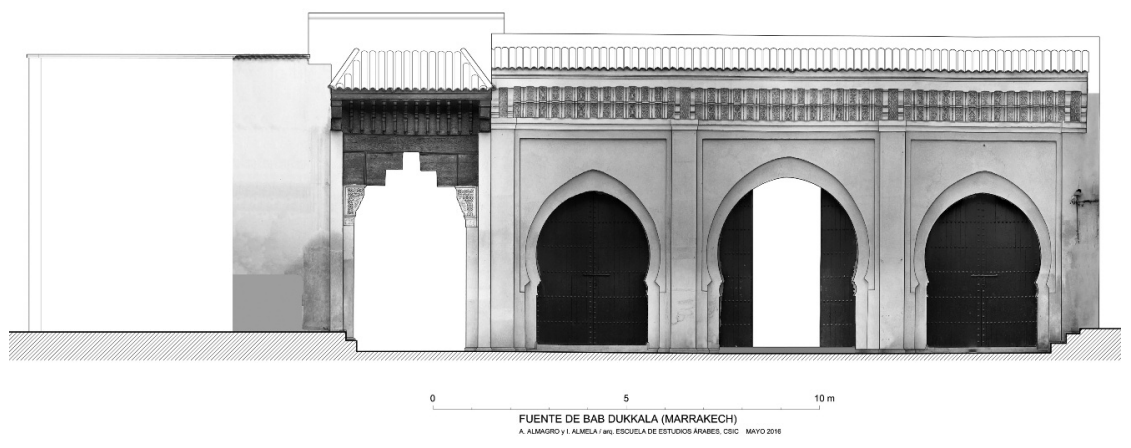

Figura 17. Fachada de la fuente-abrevadero.

${ }^{49}$ Todo este patio junto con los antiguos cuartos del imām y la biblioteca han sido privatizados recientemente y en la actualidad forman parte de una vivienda.

${ }^{50}$ Raji, La Ville de Marrakech, p. 129.

${ }^{51}$ Deverdun, Marrakech, p. 415. 
con la del complejo de al-Muwāssīn. Además, contamos con una posible referencia de este anexo en el documento de fundación de habices de 995/1585 relativo recogido por Ibn al-Qāḍī que ya hemos comentado anteriormente. En él, se dice que lālla Mas'ūda proveyó a la mezquita con rentas suficientes como para construir una fuente de agua en la que lavarse y saciar la sed ${ }^{52}$. Junto con el pabellón de abluciones, la fuente-abrevadero podría corresponder a las obras emprendidas por la madre de al-Manșūr en una segunda fase de construcción del complejo religioso.

Al igual que el resto de anexos, fue abastecida por una de las tres principales canalizaciones que aportaban la mayor parte del caudal total de agua que penetraba en la urbe. Se trata de una jațtâra, o canal subterraneo, conocida como 'ayn al-qubba que pertenecía también a los bienes habices y servía a la parte norte de la medina. Esta canalización fue probablemente la destinada al abastecimiento de la zāwiya de sīdī Abū al-'Abbās al-Sabtī y el complejo de Bāb Dukkāla ${ }^{53}$. El grupo de fuente-abrevadero-mida, debió contar con una cisterna de regulación que asegurase la emanación constante de los surtidores, al igual que vemos en los restos arqueológicos de Ibn Yūsuf. De acuerdo con los planos de la Inspection des monuments historiques de Marrakech, parece que el depósito podría corresponder con el actual espacio abovedado de la fuente, que en origen se encontraría trasdosado a la misma y separado mediante un muro ${ }^{54}$. Por el momento no sabemos si desde aquí, la derivación de un ramal podría garantizar igualmente el suministro de la pila de abluciones.

La fuente-abrevadero es de planta rectangular y consta de dos partes. Un primer espacio de menor tamaño en el extremo sur y otro que ocupa la mayor parte de la planta al norte. El más pequeño estaría destinado a la fuente para consumo humano, estando dividido en dos espacios distintos en su interior mediante un arco transversal. De esta manera queda un primer espacio de 3,75 x 2,90 m junto a la fachada y uno segundo de 3,40 x 1,80 m con forma de pila al fondo. Como sabemos por los otros ejemplos saadíes y las imágenes antiguas, este arco interior fue realizado en la restauración, eliminando así un muro que

${ }^{52}$ Ibn al-Qāḍī, Al-muntaqà al-maqșūr, p. 259.

${ }^{53}$ Luccioni, Les fondations pieuses "habous" au Maroc: depuis les origines jusqu'a 1956, pp. 108-109; Raji, La Ville de Marrakech, p. 134.

${ }^{54} \mathrm{Al}$ igual que en la fuente de al-Muwāssīn. 
cerraba el espacio más profundo. Entendemos que este espacio correspondería por tanto con la cisterna, la cual consistiría en una cámara herméticamente cerrada por sus cuatro lados. Por su parte, el espacio que la antecede sería el que funcionaría propiamente como fuente con una estrecha pila de $0,70 \mathrm{~m}$, adosada a este muro desaparecido desde donde tomarían el agua los usuarios ${ }^{55}$. Ésta última estancia está rodeada en la parte superior de los muros por dos bandas de yesería, la superior de mayor altura a base de ruedas de 16 entrelazadas y la inferior adornada con epigrafía cursiva al son de "Gloria a Dios" (al- 'izz li-Llāh). Sobre ellas, un arrocabe antecede al alfarje que cubre la estancia. Al exterior, una gran portada, abre este espacio en la fachada mediante un gran vano adintelado de $2,90 \mathrm{~m}$ de luz con dos ménsulas de yeso con mocárabes, dobles zapatas y una viga, siguiendo la tradición meriní (fig. 18). Sobre esta viga y dos pilastras laterales, descansa un alero de

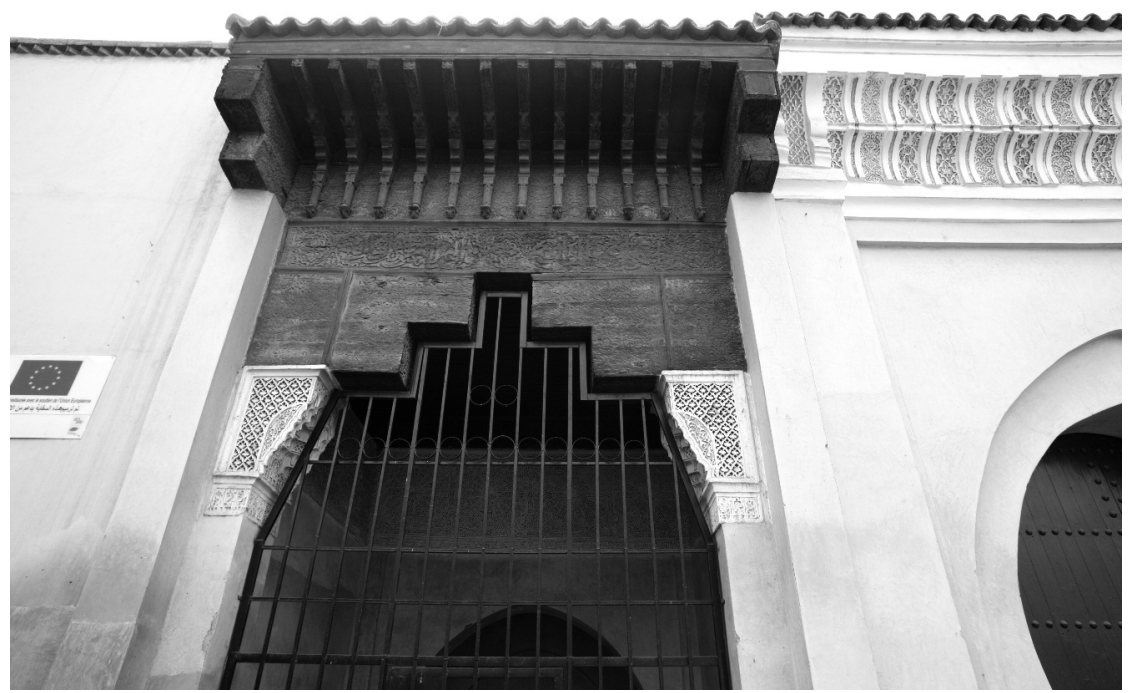

Figura 18. Portada de la fuente.

${ }^{55}$ Contamos en la ciudad con otras dos fuentes saadíes muy similares: al-Muwāssīn y "Šurub wa šûf" de las que se diferencia por tener una pila muy estrecha. Encontramos en los tres casos tallado en el dintel la misma inscripción en caracteres cursivos: "las más bellas palabras que han sido pronunciadas son alabanzas a Dios en todas las circunstancias". Los dos versos corresponden a los dos cartuchos, Deverdun, Marrakech, pp. 160-162; Ali, L'Épigraphie, p. 249. 
madera con columnillas, ménsulas y canecillos. Todo ello, queda cubierto por un tejado de tejas vidriadas verdes.

La parte septentrional es la de mayor tamaño y corresponde al antiguo abrevadero. Consiste en un gran espacio rectangular dividido por dos arcos diafragmáticos de herradura en tres módulos que están cubiertos con bóvedas de arista. A su vez, cada módulo se abre en fachada hacia la calle Lahsan u Ali mediante su respectivo arco de herradura apuntado que al exterior se enmarcan entre pilastras. Estas últimas sostienen una cornisa decorada con yeserías, similar a la que rodea el patio de la mezquita. El abrevadero actualmente transformado en un taller municipal, ha perdido su ambiente original y está cerrado con puertas. Tal y como reflejan las fotos históricas, todo este espacio era una gran piscina cubierta que contaba con un pretil exterior al que se arrimaban las bestias. Su esquema estructural recuerda a la fuente almorávide de 'Alī b. Yūsuf conservada en ruinas junto a la mida y la mezquita homónima.

Aunque hoy en día no se conserva, una pequeña escuela coránica existió en el costado este de la fuente. Según la descripción de Deverdun y las fotografías históricas, sabemos que una escalera bastante empinada permitía el acceso a la sala de estudio que se encontraba en la primera planta y que la decoración exterior se componía de una falsa arquería.

\section{El pabellón de abluciones}

Este anexo se sitúa al este de la mezquita, de la cual queda separada por una calle circundante. El pabellón ocupa un recinto casi rectangular de 22,70 x 17,30 m aproximadamente y se adosa a la espalda de la fuente-abrevadero antes descrita (fig. 19 y 20). Se compone de un patio rodeado por cuatro crujías de 2,60 $\mathrm{m}$ de altura que albergan las letrinas y un pabellón rectangular cubierto situado en el centro. Las letrinas, se abren al patio cada una con su propia puerta de $0,50 \mathrm{~m}$ de luz y están cubiertas con bóvedas de ladrillo que a veces cuentan con orificios de ventilación. Sobre ellas hay dispuesta una azotea uniforme, ligeramente inclinada que evacúa las aguas pluviales por medio de bajantes abiertas empotradas al muro. El acceso al patio se efectúa próximo al ángulo noroeste desde la calle que separa el edificio de la mezquita. El vestí- 


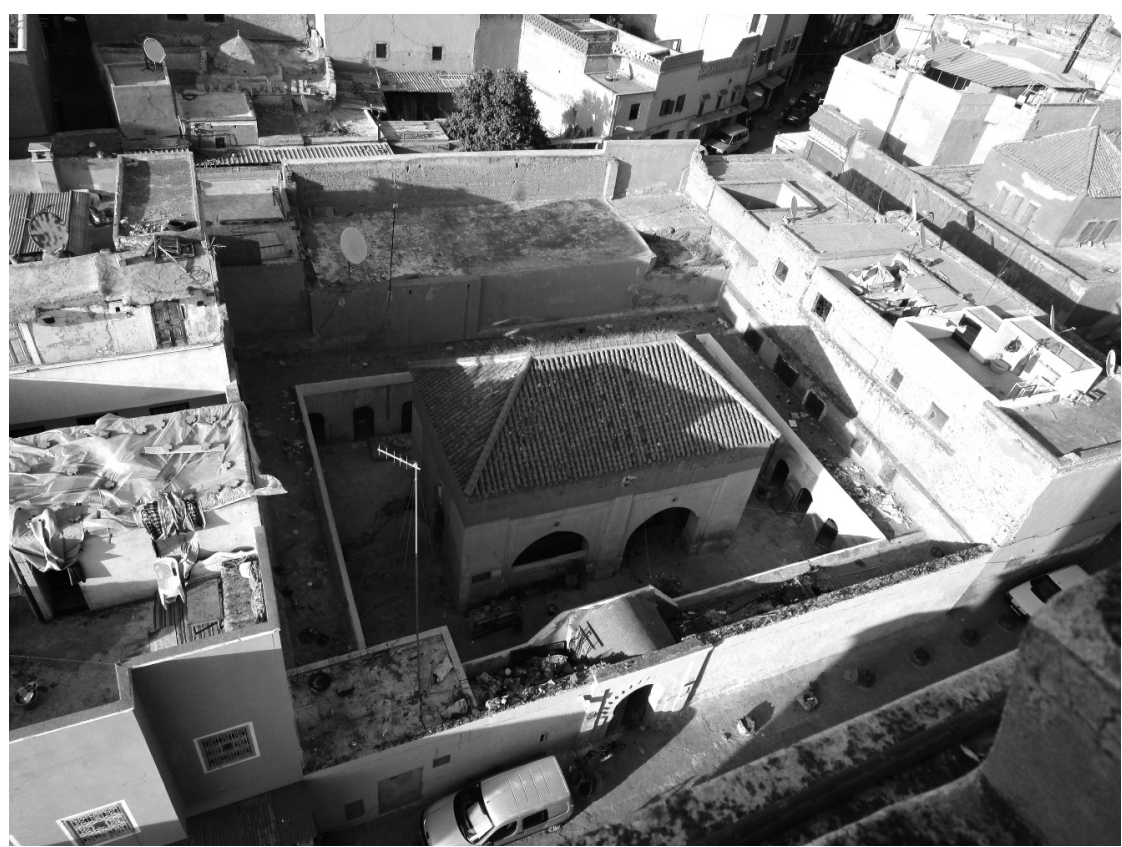

Figura 19. Manzana en la que se integran el pabellón de abluciones y la fuente-abrevadero, desde el alminar de la mezquita.

bulo abovedado está precedido por una portada exterior de casi $4 \mathrm{~m}$ de altura que se resuelve con un arco de herradura apuntado, envuelto por otro arco festoneado y enmarcado a su vez por un alfiz y dos pilastras laterales. Es notable la diferencia de cota entre la calle y el patio, para lo cual se han habilitado dos escalones en el propio ingreso.

El pabellón central es el gran protagonista del edificio por sus dimensiones y por la armadura que lo cubre (fig. 21). Tiene una planta rectangular de 11,30 × $6.30 \mathrm{~m}$ dispuesta en dirección longitudinal nortesur y alberga en su interior la pila central de abluciones ${ }^{56}$. Las fachadas este y oeste tienen cada una dos vanos con arcos apuntados aunque ambas se resuelven con un tamaño diferente. Por su parte, las fachadas

${ }^{56}$ Según Raji Elillah la pila central con su canal perimetral fue reconstruida en época tardía situándose la original a una cota más baja, cuya presencia pudo constatar mediante una grieta. Igualmente asegura que las sucesivas reformas han modificado el número de letrinas, Raji, La Ville de Marrakech, p. 137-138. 


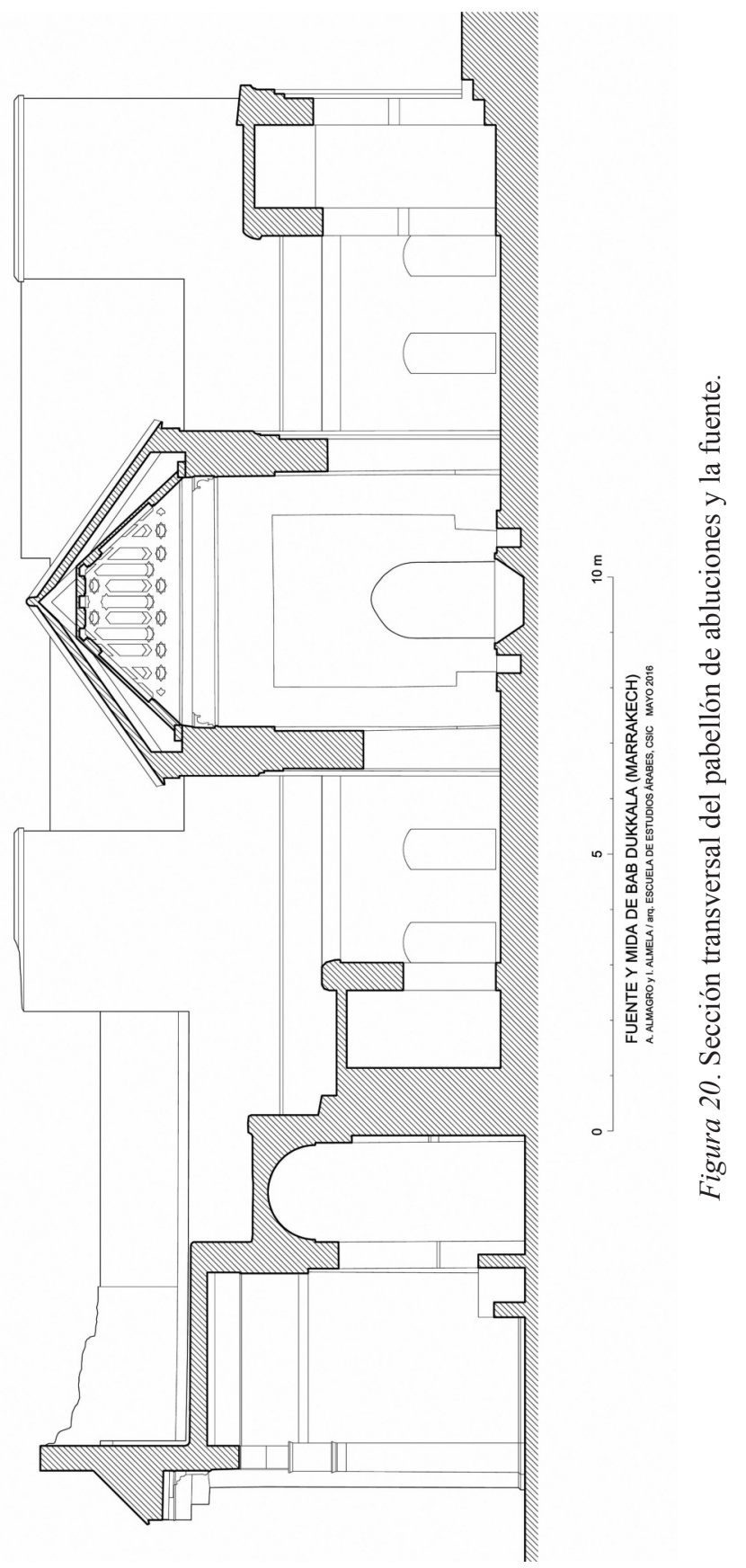

Al-Qantara XXXVIII 2, 2017, pp. 333-386 ISSN 0211-3589 doi: 10.3989/alqantara.2017.011 


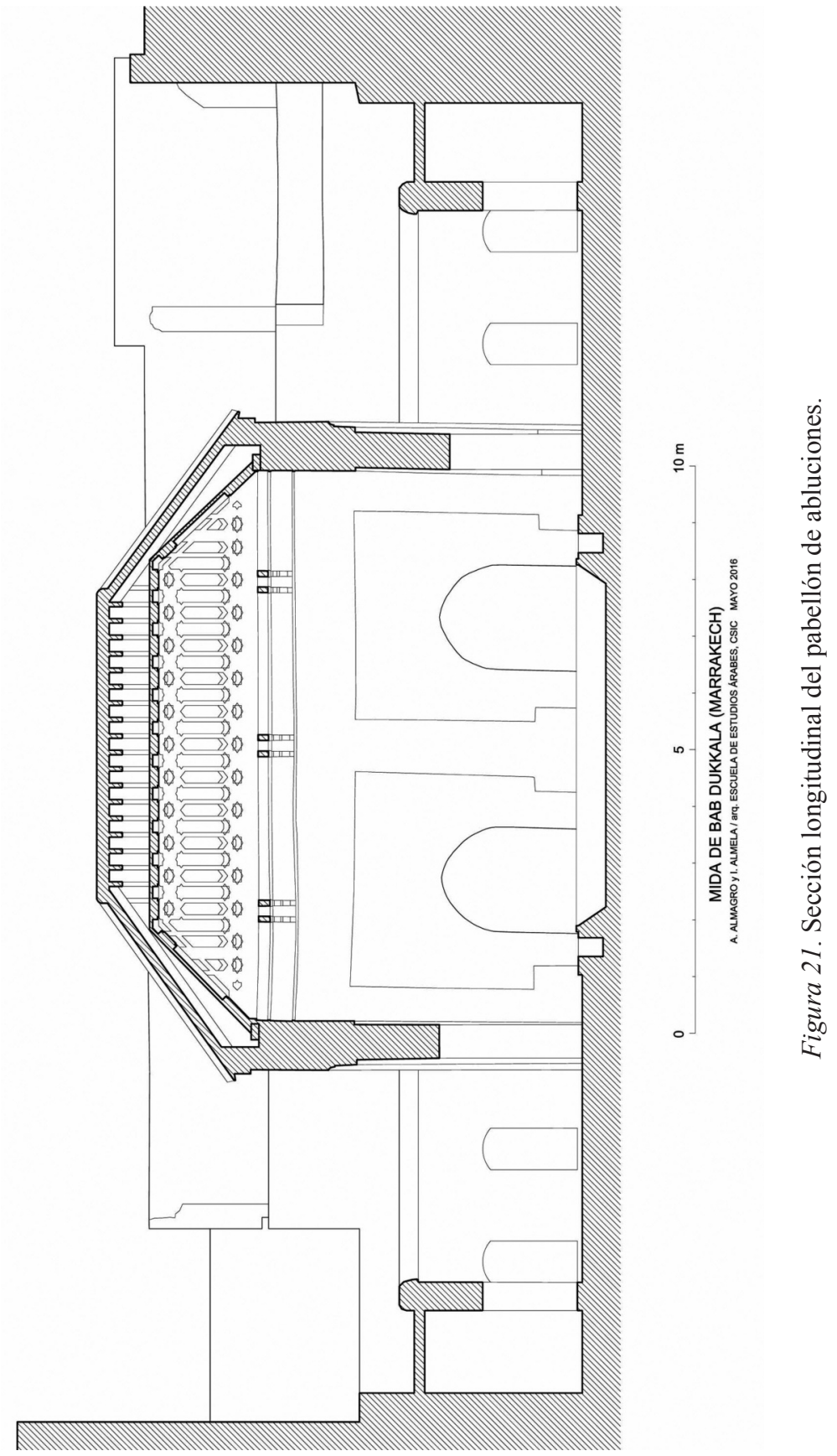

Al-Qantara XXXVIII 2, 2017, pp. 333-386 ISSN 0211-3589 doi: 10.3989/alqantara.2017.011 
menores norte y sur sólo cuentan con un reducido vano cada una. El vano septentrional del alzado oeste se sitúa frente a la puerta de acceso, y por esta razón, está provisto de un pretil de fábrica que impide ver a los usuarios desde la calle. Los vanos están enmarcados dentro de recuadros rehundidos, dejando un mayor espesor en las esquinas y en los machones centrales a modo de pilastras.

La armadura (fig. 22 y 23) que cubre el pabellón, salva una luz de 4,60 m y se puede considerar idéntica a las que cubren las naves de la mezquita. Se resuelve a base de pares y nudillos con dobles tirantes, limas moamares, y peinazos con lazo de ocho en la parte alta y baja de los faldones y en el almizate. Se diferencia únicamente por la presencia de dobles alfardas en los extremos de cada faldón, que la asemejan a su vez con la armadura que cubre la mida de al-Muwāssīn. No sabemos si nunca tuvo decoración o si la ha perdido al igual que las armaduras del interior de la mezquita. Una banda decorativa con motivos geométricos pintados en rojo almagra rodea la construcción bajo la cornisa exterior.

La evacuación de agua de las casas de abluciones, necesitó de la construcción de colectores que se ramificaban jerárquicamente por la

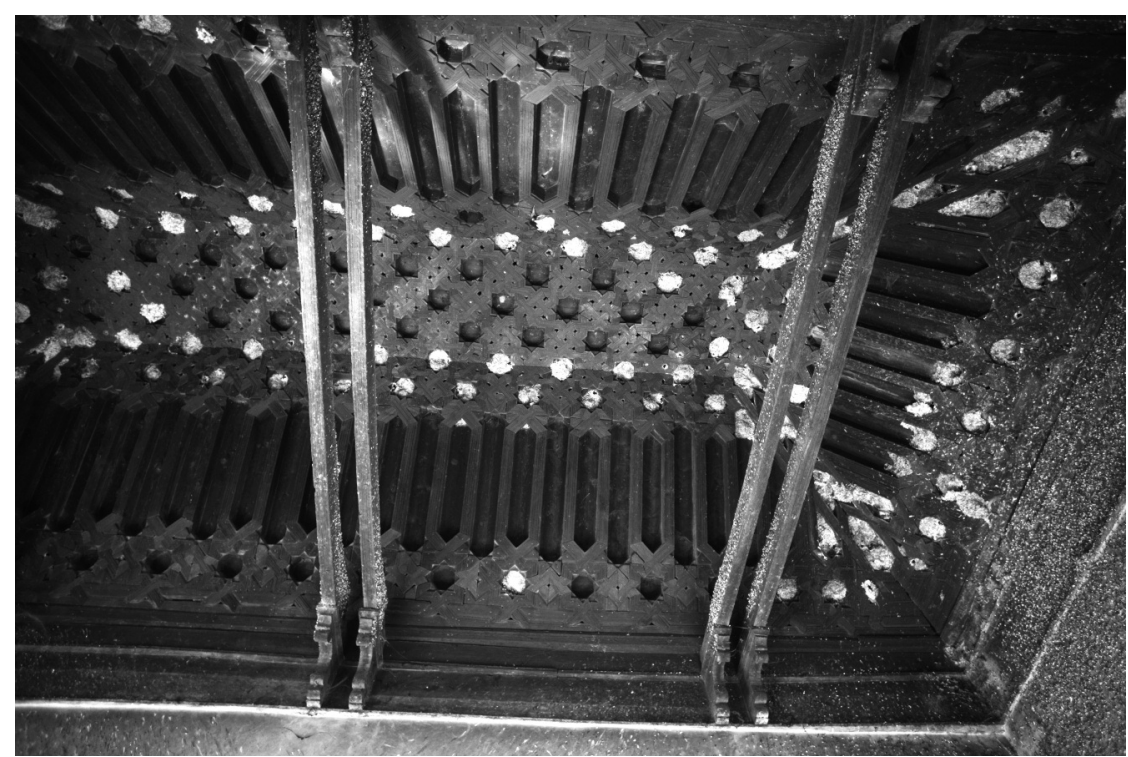

Figura 22. Carpintería que cubre la pila central de abluciones. 


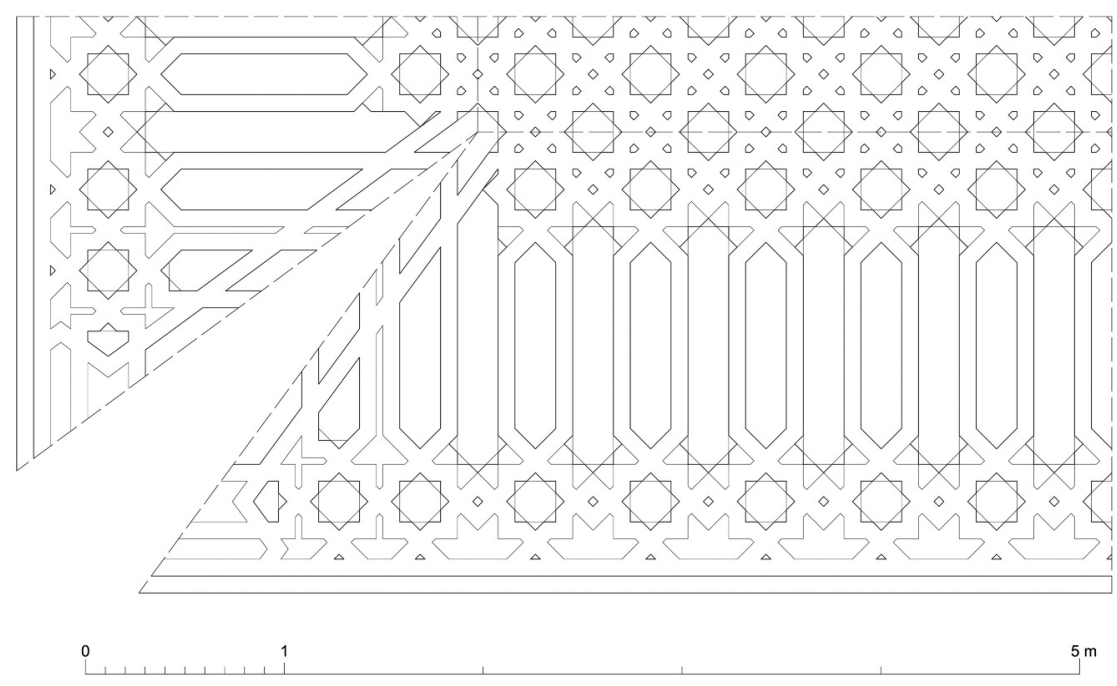

Figura 23. Plano desarrollado de un cuarto de la armadura que cubre la pila central de abluciones.

medina $^{57}$. Como apuntó Raji, probablemente los maestros de obra habrían adoptado el mismo sistema utilizado en la sala de abluciones de 'Alī b. Yūsuf y al-Muwāssīn, de modo que las canalizaciones verterían en una canalización bajo el suelo que conectaría con un colector principal de cada calle o barrio $^{58}$.

\section{El baño público (ḥammām)}

Está situado al este de la mezquita y separado de la manzana de la mida por la calle que conecta la puerta oriental de la mezquita con la arteria Sīdī 'Abd al-'Azīz. No existe a penas información sobre este edificio ni su cronología, sin embargo su función complementaria a la mezquita y su disposición dentro del conjunto guardando la misma

${ }^{57}$ En vísperas del protectorado el encargado (nāzirir) de los habices de Salé solicitó al sultán ayuda para costear la reparación del sistema de colectores de evacuación que se encontraban en mal estado, Luccioni, Les fondations pieuses, p. 76.

${ }^{58}$ Raji, La Ville de Marrakech, p. 140. 
orientación y directrices con ella, hace pensar que formara parte del mismo proyecto saadí que planificó la fuente-abrevadero y el pabellón de abluciones ${ }^{59}$. Al parecer mantiene el esquema tradicional andalusímagrebí: sala de reposo, fría, templada y caliente, estando todas ellas organizadas sobre un eje directriz longitudinal. La sala de reposo y la sala templada son de planta cuadrada y están diseñadas con una qubba central, en el primer caso se trata de una armadura y en el segundo de una cúpula de fábrica. Al sureste del edificio, un adarve proveniente de la calle Sīdī 'Abd al-'Azīz permite un ingreso de servicio a la parte trasera del baño donde se sitúa el horno y un pozo de agua. Por el momento no se ha podido realizar un levantamiento exhaustivo del interior del edificio.

\section{Paralelos}

El complejo religioso de Bāb Dukkāla representa junto con el de Muwāssīn y la zāwiya de sīdī Muhammad al-Ŷazūlī, una nueva concepción formal. Como ya se ha comentado, la disposición organizada de todos los edificios (mezquita y edificios complementarios) bajo un planeamiento racional, otorga a la arquitectura religiosa una caracterización regular perceptible en el interior de cada edificio. Todas las aproximaciones realizadas previamente para el estudio de las mezquitas saadíes han señalado la existencia de otros edificios menores construidos a su alrededor y con los que comparte una organización. Efectivamente la principal originalidad de estos proyectos es el complejo de equipamientos en el que está inscrita la mezquita y con los cuales trata de formar un conjunto arquitectónico coherente. Los anexos y equipamientos no son adiciones independientes de la mezquita, sino que forman parte de un proyecto bastante homogéneo. En Bāb Dukkāla se reproduce de forma similar el modelo del complejo de al-Muwāssīn, por lo que el posible desarrollo de su construcción en dos fases no parece haber alterado de forma apreciable el proyecto preliminar, a excepción de la disposición anómala del alminar.

\footnotetext{
${ }^{59}$ Además, contamos con el ejemplo del complejo saadí de al-Muwāssīn donde la fuente-abrevadero, la mida y el baño se establecen siguiendo una organización común.
} 
Se conoce la existencia en al-Andalus y el Magreb de midas y baños en la proximidad de las mezquitas desde época omeya, e incluso madrazas desde el siglo XIV. Destaca especialmente el ejemplo inmediato de la qubba almorávide, pabellón de abluciones de la antigua mida acompañada de una fuente y una cisterna, asociados a la mezquita de 'Alī b. Yūsuf en Marrakech. Sin embargo, lo que no sabemos es hasta qué punto estuvieron planificadas como un conjunto único dentro del proyecto de la mezquita, o por el contrario son el resultado de adiciones posteriores en el entorno de la mezquita aljama. En muchos casos fue así, primero se construyó la mezquita y posteriormente se fueron promoviendo la construcción de servicios complementarios por parte de los gobernantes y notables. Gracias a la arqueología hemos conocido ejemplos antiguos como la mida de Almanzor al este de la mezquita aljama de Córdoba e incluso sabemos que esa misma mezquita contó con otras casas de abluciones asociadas a ella y construidas en época de Hišām I y al-Hakam II $^{60}$.

Los precedentes temporales y geográficos más directos son los ejemplos de mezquitas aljamas meriníes que se concentraron especialmente en Fez y otras localidades del norte de Marruecos, así como también en Argelia ${ }^{61}$. Son numerosos los casos de mezquitas construidas por esta dinastía en los que encontramos asociados a ellas diversos anexos que siempre tienen presente la mida y el alminar ${ }^{62}$, y de manera más esporádica la biblioteca, la madraza, la escuela coránica, la mezquita funeraria y el mausoleo. Existen además casos particulares como el conjunto de Abū al-Ḥasan en Fez, el cual se encuentra conformado por una modesta mezquita y una mida yuxtapuesta; y la madraza de Abū 'Inān de Fez, en la que todos los elementos (mezquita, madraza, alminar, mida, tiendas...) están organizados dentro del mismo edificio y en torno a un gran patio. Sin embargo, el ejemplo más significativo que encontramos de esta época es el complejo de sīdī Abū Madyan fundado por el rey meriní Abū al-Ḥasan extramuros de Tremecén junto a la tumba del prestigioso místico sufí del que toma su nombre. El con-

\footnotetext{
${ }^{60}$ Montejo, "El pabellón de abluciones oriental de la mezquita aljama de Córdoba correspondiente a la ampliación de Almanzor", pp. 209-231. $\hat{\mathrm{Y}} \bar{i} \mathrm{sa}$.

${ }^{61}$ Mezquita Mayor de Taza, mezquita Mayor de Fez, Mezquita Ḥamrā’, Mezquita Bāb

${ }^{62}$ Ambos servicios son indispensables para la vida religiosa y han sido considerados como imprescindibles en los grandes oratorios, Marçais, El arte musulmán, p. 16.
} 
junto se compone de diversos edificios, algunos de ellos de mayor entidad como la mezquita y la madraza. Cuenta además al norte con el mausoleo, un palacio, residencia del procurador (wakīl) y viviendas para peregrinos ${ }^{63}$.

Lo que marca la diferencia entre estos precedentes y los casos saadíes será la manera de organizar y planificar formalmente el conjunto, especialmente el empleo de espacios públicos que estructuran las conexiones entre los diferentes edificios y que los relacionan con las arterias urbanas. Estas características parecen ser una respuesta adecuada teniendo en cuenta que los complejos fueron insertados en un tejido preexistente, aunque en el caso de Bāb Dukkāla podría estar parcialmente abandonado. Lejos de parecerse, las ciudades islámicas orientales cuentan con complejos monumentales con numerosos anexos (madrazas, hospital, comedores públicos, hospedería, baños...), que fueron ampliamente desarrollados en los siglos XIII-XIV por las dinastías Silŷūqí en Anatolia, Mameluca en El Cairo, y posteriormente por los otomanos ${ }^{64}$. Estos últimos levantaron complejos, conocidos como imâret o külliye, relativamente contemporáneos a los casos saadíes, organizados a partir de una trama de grandes calles ortogonales y plazas que articulan el engarce con el viario circundante. No obstante, no creemos que se trate de una permeabilidad a las innovaciones del otro extremo del Mediterráneo, ya que los diseños arquitectónicos saadíes parecen haber seguido rígidamente la tradición almohade-meriní. El uso del espacio público sería por tanto un recurso ante las necesidades de reactivar un barrio y de insertar un conjunto de edificios de gran tamaño en él.

Las mezquitas de al-Muwāssīn y Bāb Dukkāla, pueden considerarse como los arquetipos de las mezquitas saadíes. En líneas generales,

${ }^{63}$ Marçais, Les monuments arabes de Tlemecen, pp. 224-284.

${ }^{64}$ Ejemplo de ello son los complejos monumentales de los sultanes Mehmet II (Fatih), Beyazit II y Suleyman I en Estambul, Kuran, "A Spatial Study of three Ottoman Capitals: Bursa, Edirne and Istanbul”, pp. 128-130; Kuban, Ottoman Architecture, pp. 177-180, 195208, 277-279. El complejo de Fatih en Estambul fue levantado en un área comercial que ya existía con anterioridad a la conquista otomana, teniendo como objetivo su reactivación. Además se creó conjuntamente el nuevo espacio comercial de Saraçhane que se dirigía hacia el centro de la metrópoli, Kuban, Ottoman Architecture, pp. 177. Igualmente son de especial interés, los ejemplos construidos por altos funcionarios en Alepo, donde fueron implantados en el centro comercial de la ciudad, adaptándose al trazado urbano y generando un nuevo lenguaje visual, Kafescioglu, "In the Image of Rum: Ottoman Architectural Patronage in Sixteenth-Century Aleppo and Damascus", pp. 71-73. 
ambas adoptan el esquema fundamental almohade de planta en " $T$ " en la que resalta la importancia de la nave central y la nave transversal junto a la quibla, siempre manteniendo una simetría rígida marcada por el eje longitudinal. Esta disposición ya estaba insinuada en la mezquita de Qayrawān y en la ampliación de al-Ḥakam II en la mezquita de Córdoba (965). Tinmal representa un ejemplo ideal donde el patrón almohade fue plasmado de forma singular ${ }^{65}$; reflejando las pautas más tarde empleadas por las mezquitas saadíes. A partir de los dos ejes principales ya mencionados, se desarrollan cúpulas en los cuatro puntos principales: mihrab, macsura y ambos extremos de la nave transversal. Igualmente, la decoración se distribuye de manera jerarquizada brotando del mihrab y extendiéndose a la macsura, desde donde se propaga por medio de los ejes principales a los pórticos transversales, cúpulas y puertas. Al igual que se siguió haciendo a lo largo de los siglos XIII y XIV, el diseño de la fachada del mihrab toma como punto de partida el prototipo austero almohade basado en un arco de herradura trasdosado por arcos polilobulados enmarcados por un alfiz geométrico, sobre el cual se levanta un friso de vanos ciegos que se intercalan con celosías. Cabe mencionar que a su vez el diseño almohade toma como modelo el mihrab de al-Hakam en la mezquita de Córdoba.

Sin embargo, la proporción de su planta marca una diferencia considerable con respecto a las almohades. Hay un mayor desarrollo en el eje longitudinal, y el patio interior adquiere forma cuadrada. Éste último, aumenta en detrimento de la sala de oración, hasta tal punto que junto con sus tres pórticos casi llega a equiparar en superficie a la sala de oración ${ }^{66}$. El desarrollo meriní del modelo almohade constituye sin lugar a dudas un referente importante para las mezquitas saadíes, como ya apuntó Marçais. Estas características ya descritas del patio cuadrado y la disposición de las tres puertas, es una constante en las mezquitas más monumentales de Fez que determinaron un canon en adelante. Además, las puertas laterales se disponen en el primer módulo de la sala de oración contiguo al patio, siguiendo el modelo meriní arraigado en Tremecén (Abū Madyan, Manșūra, Sīdī al-Ḥalwī).

${ }^{65}$ Basset y Terrasse, Sanctuaires et forteresses almohades, pp. 46-56; Ewert, "The Mosque of Tinmal (Morocco) and Some New Aspects of Islamic Architectural Typology", pp. 136-141; Khiara y Leonetti, "Tinmal et la construction de la légitimité mu'minide", pp. 281-284; Elkhammar, "Contribution à l'étude des mosques almohades", pp. 320-323.

${ }^{66}$ Basset y Terrasse, Sanctuaires et forteresses almohades, p. 437. 
Igualmente, para la cúpula que precede a la 'anaza en el eje longitudinal, encontramos un referente cercano en la mezquita mayor de Fez Nuevo, donde una cúpula de doce arcos entrecruzados cubre este mismo punto. Esta mezquita, atribuida a los emires meriníes, presenta de esta manera una sección longitudinal muy similar, en cuanto a la secuencia de espacios que la componen y la distribución del programa decorativo ${ }^{67}$. No obstante, es un elemento más antiguo que ya fue empleado en la mezquita de Qayrawān. En el caso de Bāb Dukkāla, la conjunción de esta cúpula con las dos que preceden a las puertas laterales respectivamente, terminan por conformar el nártex que caracteriza a esta mezquita.

A pesar de estos aspectos, hay algunos detalles que se disocian de ese eslabón intermedio meriní, y que demuestran la intensidad con la que las mezquitas de la Kutubiyya y de la Qașba volvieron a influir, en lo que se ha considerado como la tradición almohade de Marrakech ${ }^{68}$ o el renacimiento almohade ${ }^{69}$. Un ejemplo de ello es la recuperación de un aspecto sutil que consiste en la superposición de un segundo esquema en $\mathrm{U}$ invertida conformada por la nave transversal de la quibla y las dos naves extremas ${ }^{70}$. Estas dos últimas, cuentan con una anchura de mayor dimensión (aunque ligeramente inferior a la de la nave central), y los vanos de los pórticos transversales que recaen dentro de ellas, reciben la misma atención ornamental que la nave central mediante arcos de lambrequines. Por otro lado, existe una innovación propia saadí que consiste en la proliferación de cúpulas en los módulos situados en las esquinas y junto a las puertas, efecto que vendría ocasionado por la búsqueda de semejanza con respecto a las tres cúpulas de tradición almohade situadas junto a la quibla ${ }^{71}$.

En cuanto al alminar, el programa ornamental que lo acompaña se inclina especialmente por seguir el modelo local de la mezquita almohade de al-Manșūr, en la qașba, con cuadros rehundidos del mismo tamaño en las cuatro fachadas y el uso de sebka para rellenarlos ${ }^{72}$. No

${ }^{67}$ Maslow, Les mosquées de Fès, pp. 38-53.

${ }^{68}$ Basset y Terrasse, Sanctuaires et forteresses almohades, p. 394.

${ }^{69}$ Marçais, L'architecture musulmane d'occident, p. 385.

${ }^{70} \mathrm{C}$. Ewert lo caracterizó en el caso de Tinmal designándolo como un deambulatorio de tres lados que abraza la sala de oración, Ewert, "The Mosque of Tinmal”, p. 116.

${ }^{71}$ La multiplicación de cúpulas y su distribución es un desarrollo de la temática almohade, Marçais, L'architecture musulmane d'occident, p. 385.

${ }^{72} \mathrm{El}$ alminar de al-Muwāssīn, aunque no está concluido, presenta igualmente los indicios del arranque de los pilares de ladrillo en las aristas que enmarcan los paños decorativos. 
obstante, hay un rasgo que lo distingue de la tradición almohade y meriní. Estos alminares previos, guardan todos un orden: los cuadros de sebka nacen de arquillos y se extienden sin interrupción en la mayor parte del alzado, y en caso de introducir portadas, se disponen en otros cuadros independientes dispuestos debajo de los anteriores y guardando su misma anchura. Sin embargo en Bāb Dukkāla y el resto de ejemplos saadíes se entremezclan ambas composiciones. Además, estas son de una factura más tosca y con menos refinamiento en cuanto a materiales empleados.

Como ya se ha comentado, la mida es un elemento inherente a la mezquita y en el caso de Bāb Dukkāla se integra dentro de una manzana junto con la fuente-abrevadero. La Qubba Barūdiyyīn es uno de los pocos testimonios arquitectónicos almorávides que subsisten en pie, y precisamente en la ciudad de Marrakech representa un caso excelente de pabellón de abluciones, acompañado de fuente e incluso de una cisterna, todo ello asociado a la mezquita Ibn Yūsuf ${ }^{73}$. Los resultados de la excavación que llevó a cabo Jacques Meunié en el recinto en 1952 descubrieron una pila cubierta con una rica cúpula en el centro de un patio rectangular de $13,75 \times 9,37 \mathrm{~m}$ rodeado por letrinas ${ }^{74}$. La fuente adyacente con una orientación distinta, consiste en un espacio rectangular de dimensiones interiores de 14,60 x 4,60 m, divido con arcos diafragmáticos en tres compartimentos, que se abren a modo de pórtico hacia la calle. Una gran cisterna adosada a su espalda abastecía a la fuente y a la pila de la mida, mientras que un sistema de canalizaciones evacuaba las aguas sucias de la pila central y las letrinas.

Este ejemplo de Bāb Dukkāla hunde sus raíces en la tradición local de acoplar la mida y la fuente, así como en el diseño de las mismas. Obviamente hay un gran parecido entre el abrevadero de Bāb Dukkāla y la fuente almorávide con su fachada arqueada que se abre hacia la calle. Del mismo modo que la mida, se basa en el esquema espacial de pabellón situado en un patio rodeado de cabinas. El hecho de asociar una pequeña escuela coránica a la fuente, guarda una estrecha relación con los conjuntos sabīl-kuttāb mamelucos y otomanos del Cairo ${ }^{75}$. Sin rísticas.

${ }^{73}$ A pocos metros se localiza un baño del que desconocemos su cronología y caracte-

${ }^{74}$ Deverdun, Marrakech, pp. 415-416; Meunié, Terrasse y Deverdun, Nouvelle recherches arquéologiques a Marrakech, pp. 6-20.

${ }^{75}$ Kaḥlāwī, "al-Siqāyāt al-Magribiyya bi-madīnatai Fās wa-Marākeš". 
embargo, no podemos incidir en este aspecto puesto que la construcción destinada a escuela coránica desapareció, y a tenor de lo que se observa en las fotografías antiguas (fig. 24) parece tratarse de una adición posterior ${ }^{76}$.

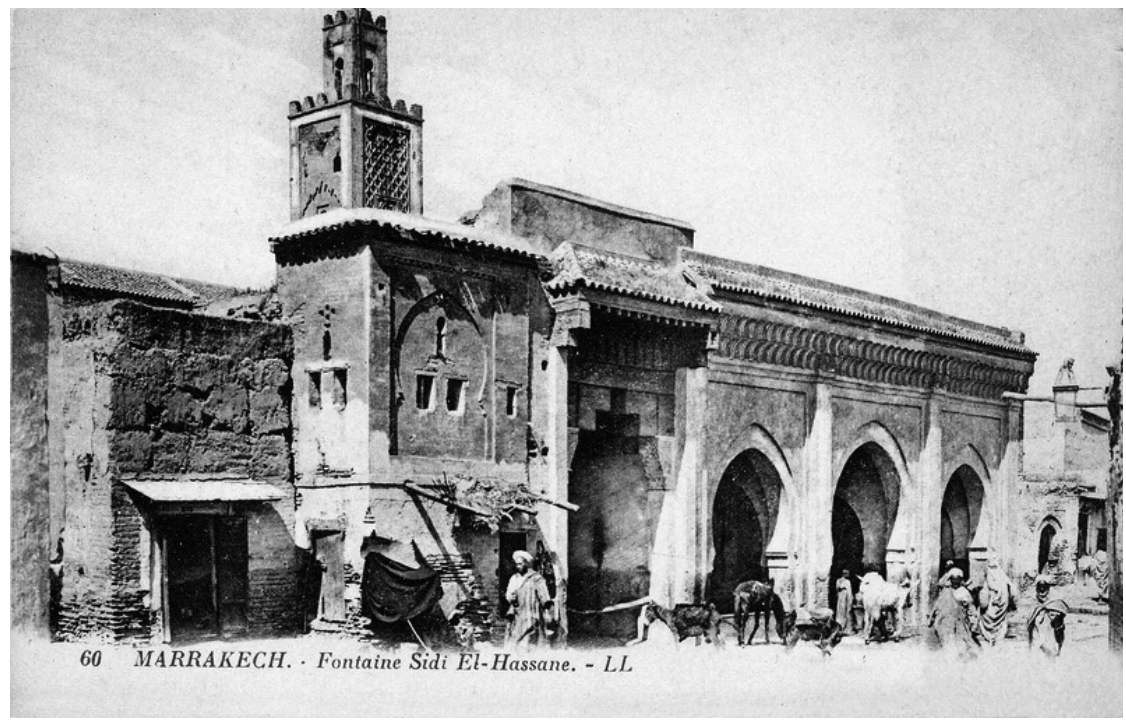

Figura 24. Foto antigua de la fuente-abrevadero con la posible escuela coránica adosada a su izquierda.

\section{Bibliografía}

Ali, Rasha, L'Épigraphie monumentale sa'dienne au Maroc, tesis doctoral dirigida por Jean Pierre Van Staëvel en la Universidad de París-Sorbonne, 2008.

Almagro, Antonio, "Jardín con plantas (y alzados) de papel”, en Alfonso Jiménez (ed.), Arquitectura en Al-Andalus. Documentos para el siglo XXI, Barcelona, Granada, Fundación El Legado Andalusí, 1996, pp. 205-284.

Almagro, Antonio, “Análisis arqueológico del pabellón occidental del palacio alBadi“ de Marrakech”, Arqueología de la Arquitectura, 10, e008, 2013.

Almagro, Antonio, "El Salón Norte del Palacio al-Badi’ de Marrakech: Estudio arqueológico e hipótesis sobre su forma original", Arqueología de la Arquitectura, 11, e016, 2014.

\footnotetext{
${ }^{76}$ Este aspecto se verá más claramente en el caso de la fuente de al-Muwāssīn.
} 
Almagro, Antonio, Navarro, Julio y Orihuela, Antonio, "Metodología en la conservación del patrimonio arquitectónico medieval", en Saiz-Jiménez, C., Rogerio-Candela, M.A. (eds.), La Investigación sobre Patrimonio Cultural, Sevilla, CSIC, 2008, pp. 87-98.

Barrucand, Marianne, Urbanisme princier en Islam: Meknès et les villes royales islamiques post-médiévales, París, Librairie Orientaliste Paul Geuthner, 1985.

Basset, Henri y Terrasse, Henri, Sanctuaires et forteresses almohades, París, Larosse, 1932.

Boloix, Barbara, Las sultanas de la Alhambra: las grandes desconocidas del reino nazari de Granada (siglos XIII-XV), Granada, Comares, 2013.

Calvo, Susana, Las mezquitas de al-Andalus, Almería, Fundación Ibn Tufayl de Estudios Árabes, 2014.

Deverdun, Gaston, Inscriptions arabes de Marrakech, Rabat, Institut des Hautes Études Marocaines, 1956.

Deverdun, Gaston, Marrakech des origines à 1912, Rabat, Èditions Techniques Nord-Africaines, 1959-1966.

Elkhammar, "Le mobilier des mosquées médiévales du Maroc d'après les sources textuelles", Al-Andalus-Magreb, 13 (2006), pp. 79-94.

Elkhammar, Abdeltif, "Contribution à l'étude des mosques almohades", en Lintz, Yannick y Déléry, Claire (eds.), Le Maroc médiéval. Un empire de l'Afrique à l'Espagne, París, Hazan, 2014, pp. 319-363.

Ewert, Christian, "The Mosque of Tinmal (Morocco) and Some New Aspects of Islamic Architectural Typology", Proceedings of the British Academy, 72 (1986), pp. 115-148.

Ibn 'Abd al-Malik al-Marrākušī, Muhammad, al-Ḍayl wa-l-Takmila li-kitābay alMawșūl wa-l-Ṣila, ed. Muḥammad Ibn Šarīfa y Iḥsān 'Abbās, Beirut-Rabat, Dār al-Taqāfa-Akādimiyyat al-Mamlaka al-Magribiyya, 1964-1984.

Ibn al-'Askar, Muḥammad, Dawhat al-nāṣir li-maḥāsin man kāna bi-l-Magrib min mašāyj al-qarn al- 'âsir, ed. Muhammad Haŷŷ̄, Casablanca, Manšūrāt Markaz al-Turāt al-Taqāfī al-Magribī, 2003.

Ibn al-Qāḍī, Aḥmad, Durrat al-hîyâl fi asmā'i al-riŷāl, ed. I. S. Alūš, Rabat, AlMaṭba'a al-ŷadīda, 1934.

Ibn al-Qāộ̄, Aḥmad, al-Muntaqà al-maqșūr 'alà ma 'àtīr al-jalīfa al-Manșūr, ed. Muhammad Razzūq, Rabat, Maktabat al-Ma‘ārif, 1986.

Al-Ifrān̄̄, Muhammad, Nozhet-Elhâdi, histoire de la dynastie saadienne au Maroc (1511-1670), trad. O. Houdas, París, Ernest Leroux, 1889.

Kafesçioglu, Çigdem, "In the Image of Rum: Ottoman Architectural Patronage in Sixteenth-Century Aleppo and Damascus", Muqarnas, 16 (1999), pp. 70-96. Kaḥlwaī, Muḥammad, "al-Siqāyāt al-Magribiyya bi-madīnatai Fās wa Marākeš. Dirāsa atāriyya muqārana ma'a al-Asbila al-Mamlukiyya bi-al-Qāhira”, Bulletin of the Faculty of Arts, 4, University of Qina (Egipto), 1995, pp. 317-384. 
Khiara, Youssef y Leonetti, Bulle Tuil, "Tinmal et la construction de la légitimité mu'minide", en Lintz, Yannick y Delery Claire (eds.), Le Maroc médiéval. Un empire de l'Afrique à l'Espagne, París, Hazan, 2014, pp. 281-289.

Kuran, Aptullah, "A Spatial Study of three Ottoman Capitals: Bursa, Edirne and Istanbul”, Muqarnas, 13 (1996), pp. 114-131.

Kuban, Dogan, Mill, Adair y Emden, Cemal, Ottoman architecture, Woodbridge, Antique Collectors' Club, 2010.

Levi-Provençal, Évariste, Les historiens des Chorfa: essai sur la littérature historique et biographique au Maroc du XVIe au XXe siècle, París, Larousse, 1922.

Luccioni, Joseph, Les fondations pieuses 'habous' au Maroc: depuis les origines jusqu'a 1956, Rabat, Imprimerie Royale, 1982.

Marçais, Wiliam y Marçais, Georges, Les monuments arabes de Tlemecen, París, Fontemoing, 1903.

Marçais, Georges, L'architecture musulmane d'occident: Tunisie, Algérie, Maroc, Espagne et Sicilie, París, Arts et Metiers Graphiques, 1954.

Marçais, Georges, El arte musulmán, Madrid, Cátedra, 1983.

Maslow, Boris, Les mosquées de Fès et du nord du Maroc, París, Editions d'art et de histoire, 1937.

Meakin, James E. Budgett, The land of the Moors, Londres, S. Sonnenschein \& Company, 1901.

Meunié, Jacques, Terrasse, Henri y Deverdun, Gaston, Nouvelle recherches arquéologiques a Marrakech, París, Arts et metiers graphiques, 1957.

Miles, G.C., "“Anaza”, en P. Bearman, Th. Bianquis, C.E. Bosworth, E. Van Donzel, W.P. Heinrichs (eds.), Encyclopedia of Islam, Second Edition, 2012. [en línea], disponible en: http://dx.doi.org/10.1163/1573-3912_islam_SIM_0655, [consultado el 27/02/2018].

Montejo, Alberto, "El pabellón de abluciones oriental de la Mezquita Aljama de Córdoba correspondiente a la ampliación de Almanzor", Cuadernos de Madinat al-Zahra, 4 (1999), pp. 209-231.

Al-Nāṣirī, Aḥmad ibn Ḥālid, Kitāb al-Istiqșā li-ajbār al-Magrib al-Aqsà, ed. Ŷa'far al-Nāṣirī y Muḥammad al-Nāṣirī, 5 vols., Casablanca, Dār al-Kitāb, 1997.

Navarro, Julio y Jiménez, Pedro, Las ciudades de Alandalús. Nuevas perspectivas, Zaragoza, Instituto de Estudios Islámicos, 2007.

Nuere, Enrique, Carpintería de armar española, Madrid, Instituto de Conservación y Restauración de Bienes Culturales, 1990.

Fierro, Maribel, "El espacio de los muertos: fetuas andalusíes sobre tumbas y cementerios", en Maribel Fierro, Jean-Pierre van Staëvel y Patrice Cressier (eds.), L'urbanisme dans l'occident musulman au moyen âge: aspects juridiques, Madrid, CSIC, 2000, pp. 153-190.

Raji Elillah, Youssef, La Ville de Marrakech sous les Sa'adiens (16-17ème siècles): L'activité architecturale et le développement urbain, tesis doctoral dirigida por Marianne Barrucand en la Universidad de Paris-Sorbonne, 1996. 
Terrasse, Henri y Deverdun, Gaston, La Mosquee al-Qaraouiyin a Fes, París, Librairie C. Klincksieck, 1968.

Trillo Sanjosé, Carmen, "Mezquitas en al-Andalus: un espacio entre las comunidades y el poder", Studia Historica. Historia Medieval, 29 (2011), pp. 73-98.

Vajda, Georges, "Un recueil de textes historiques judéo-marocains", Col. Hespéris, XII, P.I.H.E.M., 1951.

Wilbaux, Quentin, La médina de Marrakech: formation des espaces urbains d'une ancienne capitale du Maroc, París, L'Harmattan, 2001.

Recibido: $23 / 02 / 2017$

Aceptado: 20/12/2017 